\title{
MINERALOGY AND WEATHERING OF REALGAR-RICH TAILINGS AT A FORMER As-Sb-Cr MINE AT LOJANE, NORTH MACEDONIA
}

\author{
TAMARA ĐORĐEVIĆ \\ Institut für Mineralogie und Kristallographie, Universität Wien, Althanstr. 14, 1090 Wien, Austria
}

UwE KOLITSCH

Mineralogisch-Petrographische Abteilung, Naturhistorisches Museum, Burgring 7, 1010 Wien, Austria Institut für Mineralogie und Kristallographie, Universität Wien, Althanstr. 14, 1090 Wien, Austria

TODOR SERAFIMOVSKI AND GorAN TASEV

Department of Mineral Deposits, Faculty of Natural and Technical Sciences, University “Goce Delčev"-Štip, Goce Delčev 89, 2000 Štip, North Macedonia

NATHALIE TEPE

Department of Environmental Geosciences, University of Vienna, Althanstr. 14, 1090 Wien, Austria

MichaEL STÖGER-POLLACH

University Service Centre for TEM, Technische Universität Wien, Wiedner Hauptstr. 8-10, 1040 Wien, Austria

\section{THILO HOFMANN}

Department of Environmental Geosciences, University of Vienna, Althanstr. 14, 1090 Wien, Austria

\section{BLAŽo BOEV}

Department of Mineral Deposits, Faculty of Natural and Technical Sciences, University “Goce Delčev"-Štip, Goce Delčev 89, 2000 Štip, North Macedonia

\begin{abstract}
In the Lojane area (North Macedonia) ores of Sb (stibnite), As (realgar), and $\mathrm{Cr}$ (chromite) were mined and processed in a metallurgical plant until 1979. Over one million tons of flotation tailings containing As, Sb, and other hazardous substances are located in an open dump site for flotation waste created by the mine. The tailings site is completely unprotected, and its orange color reflects a very high concentration of arsenic (fine-grained realgar superficially altered to pararealgar). In order to better understand the weathering behavior of these tailings, which is necessary to evaluate the environmental risks (mainly from the mobilization of As-Sb-Cr), solid waste material was sampled and studied from the chemical and mineralogical point of view. The material was characterized by inductively coupled plasma-mass spectrometry (ICP-MS), inductively coupled plasmaoptical emission spectrometry (ICP-OES), X-ray diffraction analysis (both single crystal and powder), scanning electron microscopy (SEM) with energy-dispersive microanalysis (EDX), Raman spectroscopy, and transmission electron microscopy (TEM) with selected area electron diffraction (SAED), energy-dispersive X-ray analysis (EDX), and electron energy loss spectrometry (EELS). The studied tailings material is comprised mostly of well-crystallized realgar, gypsum, and quartz, and minor amounts of stibnite, pararealgar, chromite, and sulfur. Very minor pyrite is found within quartz aggregates. The most abundant secondary phase, which forms thin coatings around realgar and stibnite grains, is an As-Sb-Fe-Ca-(Ni)-oxide/ hydroxide in which the As:Sb ratio varies from $c a$. 2:1 to 1:2.2 and Fe contents are variable. Antimony-dominant variants of
\end{abstract}

\footnotetext{
$\S$ Corresponding author e-mail address: tamara.djordjevic@univie.ac.at
} 
this oxide also form larger homogeneous grains up to $500 \mu \mathrm{m}$ in size, characterized by broad dehydration cracks suggesting original formation as a gel. Both As-rich and -poor variants were identified as members of the roméite group. EELS showed that all the $\mathrm{Fe}$ is ferric. Further secondary phases originated from the weathering of realgar, stibnite, and other primary phases are As-bearing sulfur, scorodite (often slightly Sb-bearing, locally common), arsenolite, "limonite", pickeringite (Ni- and Febearing), alunogen, and annabergite. The weathering of primary sulfides in the flotation tailings at Lojane proceeded under mostly oxidizing, acidic, and temporarily wet conditions. Highly acidic conditions on the surface of the tailings dump imply dissolution of arsenolite and scorodite, thus causing contamination of the environment and high mobility of arsenic.

Keywords: arsenic, realgar, antimony, tailings, oxidation, weathering.

\section{INTRODUCTION}

Arsenic (As) has been classified as one of the major pollutants by the United States Environmental Protection Agency (USEPA 2009), contested in its toxicity by only a few other elements. Like As, antimony ( $\mathrm{Sb})$ is classified as a priority pollutant by the same Agency and has been assigned to the group of substances suspected of being carcinogenic to humans by the International Agency for Research on Cancer.

One of the major sources of $\mathrm{As}$ and $\mathrm{Sb}$ in the environment is mine wastes, which contain tens to tens of thousands of ppm of arsenic and tens to thousands of ppm of antimony (Kossoff et al. 2015 and references therein). Most of the environmental risks concerning mine wastes are due to the constant element release from mechanically unstable, chemically labile, and non-remediated mine tailings and from abandoned former mine sites where waste materials are subjected to atmospheric conditions, underground or meteoric waters, or biotic effects (organisms living on the site or nearby). These alteration processes lead to contamination of the environment in addition to a general background level of contamination (Hudson-Edwards 2016).

One of the ways to reduce the risk posed by exposure to $\mathrm{As}$ and $\mathrm{Sb}$ is the precipitation of secondary minerals, especially those that are less soluble and have low bioavailability. Through both weathering and alteration by ore processing of primary As and $\mathrm{Sb}$ minerals, secondary oxides and oxysalts of As and $\mathrm{Sb}$ are formed. Native As, As-bearing sulfides (arsenopyrite, As-bearing pyrite, realgar, orpiment), and Asbearing sulfosalts (e.g., enargite, tennantite) are the most widespread primary arsenic minerals in miningaffected environments. Weathering of these arsenic minerals generally releases arsenic into the environment and thus potentially causes significant contamination. The released As can precipitate as various secondary arsenic minerals that contain structural arsenic. These comprise Fe arsenates such as scorodite and kaňkite, Fe sulfoarsenites such as tooeleite, $\mathrm{Ca}-\mathrm{Fe}$ arsenates such as arseniosiderite, yukonite, and related amorphous forms, and $\mathrm{Ca}(-\mathrm{Mg})$ arsenates such as pharmacolite and picropharmacolite (Drahota \& Filippi 2009, Majzlan et al. 2014). These precipitation processes cause the sequestration of active arsenic species, significantly reducing the arsenic toxicity in the environment. Arsenic can also be incorporated in trace amounts in a variety of minerals such as Fe, Mn, or $\mathrm{Al}$ oxides, $\mathrm{Fe}, \mathrm{Mn}$ or $\mathrm{Al}$ hydroxides, $\mathrm{Fe}, \mathrm{Mn}, \mathrm{Al}$ sulfates, other hydrous and anhydrous sulfates, phosphates, and hydrous silicates (Majzlan et al. 2011). In these cases, the arsenic is taken up by sorption onto the mineral surface (Mohan \& Pittman 2007) or incorporated into the mineral structure by co-precipitation. The importance of such processes in modifying arsenic bioavailability indicates a continued need to investigate secondary As-bearing minerals and related phase transformations that occur in sulfide mine environments, in order to improve our understanding of the environmental geochemistry of As.

Antimony is mined mostly from hydrothermal ores that are usually dominated by stibnite. Other primary $\mathrm{Sb}$ sulfides and rare sulfosalts may be present in smaller amounts (Roper et al. 2012). In hydrothermal ores, antimony may be present in appreciable amounts even if it is not targeted as the element of interest (e.g., in tetrahedrite) and, therefore, will be included in ore processing and disposal of waste. If exposed to the ambient atmosphere, the primary $\mathrm{Sb}$ sulfides give way to a limited number of Sb-bearing secondary minerals (Roper et al. 2012). In tailings impoundments, the primary or secondary minerals can be converted to tertiary minerals typical for these settings. The environmental mobility of $\mathrm{Sb}$ has been evaluated using various sequential leaching protocols or dissolution studies (Ashley et al. 2003, Flynn et al. 2003 and references therein). These authors concluded that the oxidation of stibnite is rapid. The products of this oxidation are the $\mathrm{Sb}$ oxide minerals senarmontite, valentinite, stibiconite, or rarely cervantite. The solubility of these minerals is variable; in a sufficient water flow, they may slowly release $\mathrm{Sb}$ into the environment. However, at most of these sites, secondary $\mathrm{Fe}$ oxides form a formidable barrier to $\mathrm{Sb}$ mobility (Ashley et al. 2003, Majzlan et al. 2007). Therefore, as long as these Fe oxides are not disturbed, 
Sb may not be bioavailable (Flynn et al. 2003), although there seem to be some exceptions (Burton et al. 2019).

Large amounts of mining and processing waste were generated at the Lojane site ( $\mathrm{Sb}-\mathrm{As}-\mathrm{Cr}$ deposit) in northeast North Macedonia during the second half of the last century and the remediation of this site has not proceeded despite United Nations Environment Programme (UNEP) and United Nations Development Programme (UNDP) initiatives in the mid-2000s (UNEP 2000, JICA et al. 2008, Williams \& Marstijepović 2010). Since the mineralogical composition of mining wastes is the key factor that controls retention and release of pollutants, the major aim of this study was the characterization of the crystalline primary and secondary minerals of the mine-waste materials and of the amorphous and poorly crystalline secondary mineral phases.

The literature on the mineralogical composition of the Lojane deposit is fairly poor, consisting mostly of a very few scientific articles and conference reports from the 1930s to the 1960s, some only in Serbian or Macedonian (Hiessleitner 1931, 1934, 1951, Radusinović 1956, 1966, Janković 1960, Antonović 1965, and references therein). To our knowledge, the weathering products of the primary minerals as well as the mineralogy of the various mine waste materials have not been studied.

We have started to study the environmental mineralogy and geochemistry of the Lojane Sb-As$\mathrm{Cr}$ deposit in detail in a four-year project (1/2018-12/ 2021), which was preceded by a smaller mobility support bilateral research project between Austria and Macedonia (07/2016-06/2018) that aimed to characterize weathering products in various dumps of the Lojane deposit. A first study focusing on the mineralogy of secondary phases detected on weathered ore-bearing waste dumps (i.e., excluding the flotation waste) has been published by our group (Kolitsch et al. 2018).

The present study focuses only on how As, $\mathrm{Sb}$, and other toxic elements are hosted in the oxidation products of the realgar-rich flotation tailings. Using freshly collected samples from these tailings, which contain very abundant realgar and pararealgar (on average 60 wt.\%), as well as notable amounts of stibnite (between 5.9 and 13.45 wt.\% stibnite), we have characterized pre-weathering phases and weathering products using inductively coupled plasma-mass spectrometry (ICP-MS), inductively coupled plasmaoptical emission spectrometry (ICP-OES), X-ray diffraction analysis (both single crystal and powder), scanning electron microscopy (SEM) with energydispersive microanalysis (EDX), Raman spectroscopy, and transmission electron microscopy (TEM) with selected area electron diffraction (SAED), energy- dispersive X-ray (EDX), and electron energy loss spectroscopy (EELS). We use these results to discuss the natural oxidation of realgar and stibnite and associated implications for the transformation and mobility of As and Sb.

\section{Site Description and Geology}

\section{Site description}

The abandoned Sb-As-Cr deposit Lojane in northeast North Macedonia is located near the border with Serbia and Kosovo, between the villages of Lojane and Vaksince (Fig. 1). The mine presents a major environmental problem for North Macedonia. The site is located near two villages and a local school. It presents a very serious human health risk, given the high concentration of arsenic wastes (Alderton et al. 2014 and references therein).

The mine exploited and processed As-, Sb-, and Crores in the period between 1923 and 1979. Over one million tons of tailings containing $\mathrm{As}, \mathrm{Sb}$, and other hazardous substances are located in an open dump site for flotation waste created by the mine (Fig. 2a). The production and beneficiation facilities, ore waste dumps, and tailings ponds were abandoned without carrying out any conservation or protective measures. The waste material is estimated to comprise $20,000 \mathrm{t}$ at the mine site and 15,000 $\mathrm{t}$ of arsenic concentrate and $3,000,000 \mathrm{t}$ of tailings at the concentration facility (Antonović 1965). The tailings dump (42.217303 N, $21.664378 \mathrm{E}$ ) is completely unprotected and its orange color suggests a very high concentration of realgar and its weathering products (Alderton et al. 2014). The concentrate was transported by small gauge railway to a location next to the main railway line at Čivluk. There are also the remains of the old arsenic smelter (Fig. 3). The smelter site contains a large pile of arsenic concentrate and is covered with numerous heaps of black and white powder. These consist of stibnite concentrate and refined arsenolite and are assumed to be the remains of 2500 wooden barrels of processed material, which were abandoned and left to rot.

The potential environmental risk includes elevated concentrations of $\mathrm{As}$ and $\mathrm{Sb}$ leaching out of flotation tailings into the surrounding soils, ground, and surface waters (Tasev et al. 2017). The $\mathrm{pH}$ values of ground waters near the studied flotation tailings are around 8 (Alderton et al. 2014). The soils in the immediate vicinity of the flotation tailings exhibit very high concentrations of $\mathrm{As}, \mathrm{Sb}$, and Ni. Furthermore, Janković (1989) reported an increased Tl content in the realgar from Lojane (100-1000 ppm). The tailings material is exposed to the weather, resulting in continued physical transport via rivers and wind- 

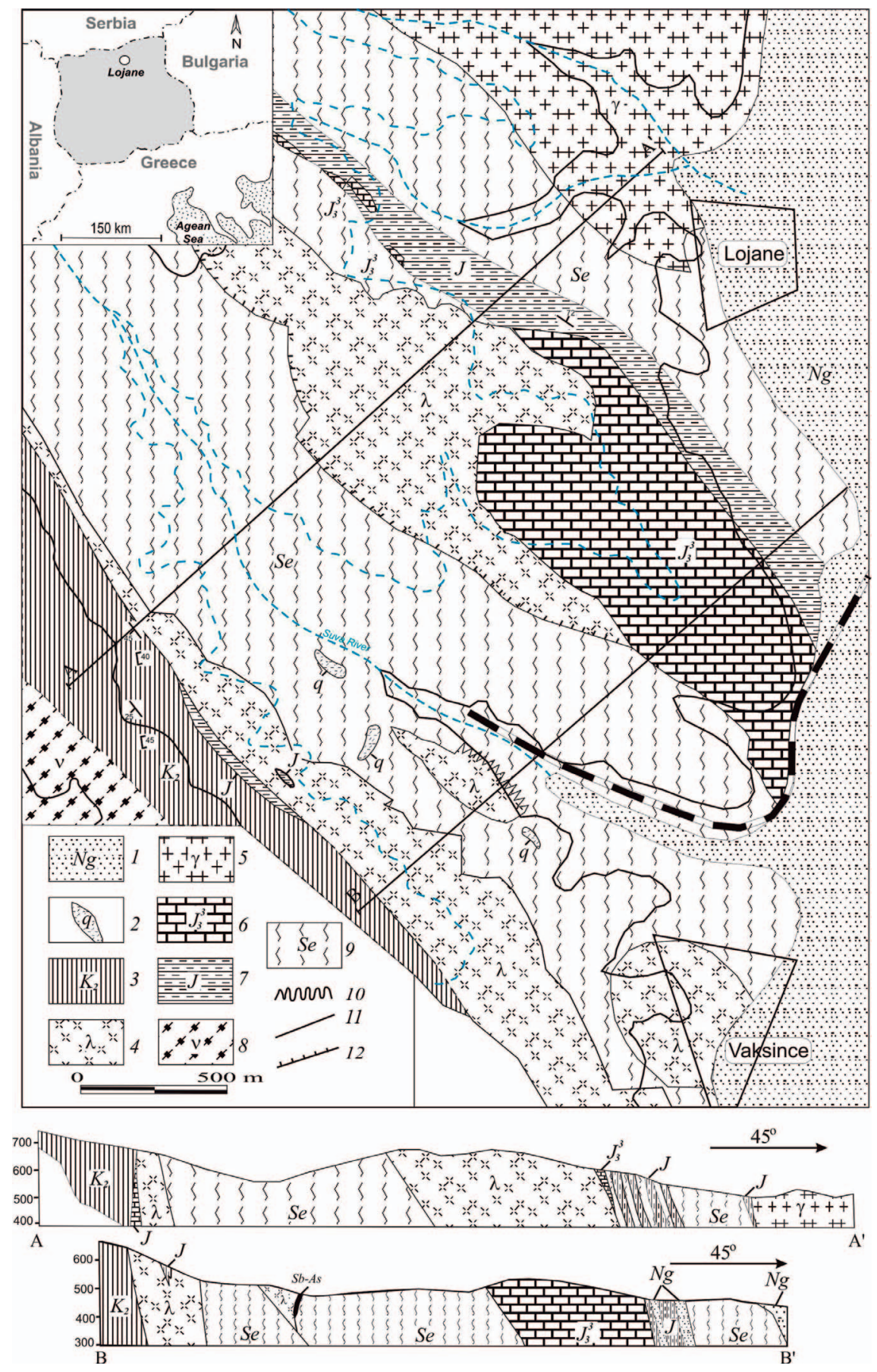

FIG. 1. Geological map of the Lojane deposit area (Tasev et al. 2017, adapted from Antonović 1965): (1) diluvial and Neogene deposits; (2) silicified serpentine; (3) Upper Cretaceous flysch; (4) quartz-porphyry (rhyolite); (5) granite, syenite; (6) Upper Jurassic massive limestone; (7) black shale, sandstone (diabase-hornfels formation, Jurassic); (8) gabbro, diorite; (9) serpentinite and peridotite; (10) realgar (As) and stibnite (Sb) mineralization; (11) normal fault; (12) reverse fault. 



\section{(d)}
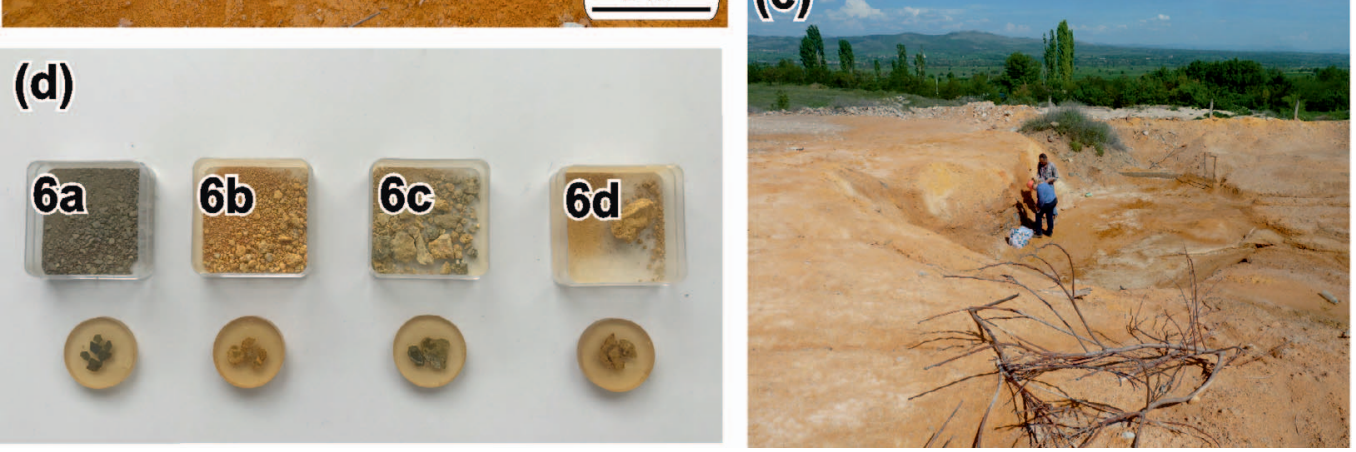

Fig. 2. Information about samples: (a) open dump site for flotation waste; (b) ellipsoid-shaped hole, from which samples 6a-6d were taken; (c) sampling points; (d) part of the sample material and their resin-mounted polished sections; and (e) sampling profiles. 


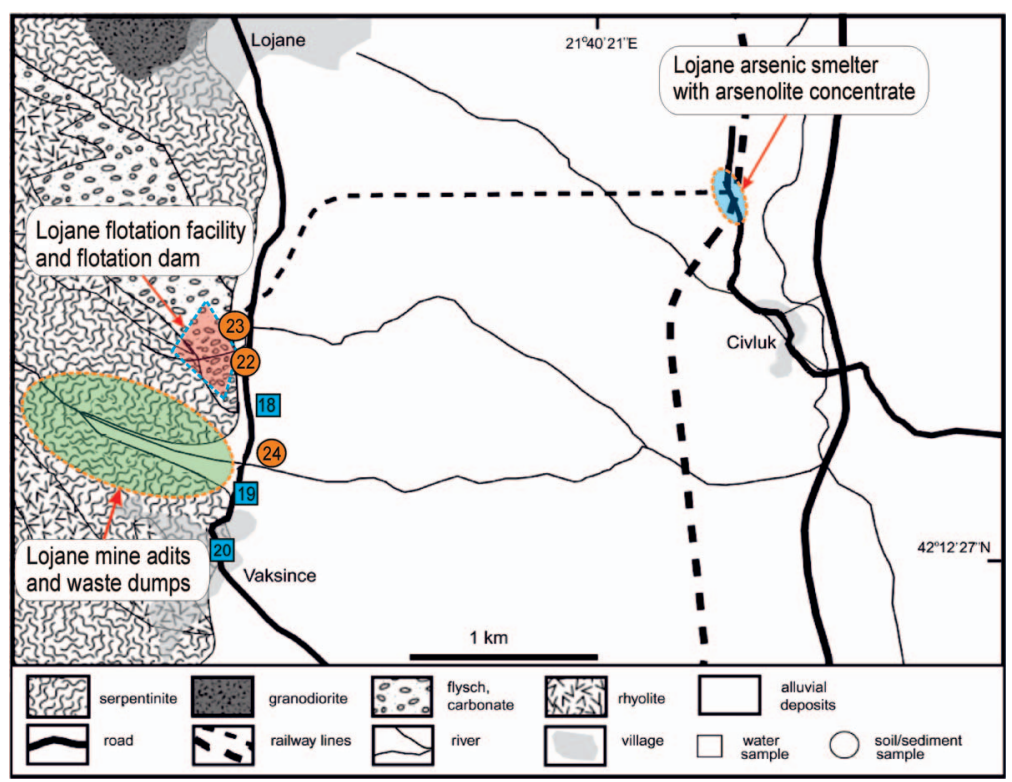

FIG. 3. Topographic map of the Lojane area with locations of the zones of interest. Sampling points for water are marked as blue squares and those for soil and sediment samples as light orange circles.

blown dust, as well as chemical weathering and transport in solution, which increases the environmental impact. The climate in the Lojane area (altitude: about 440 to $640 \mathrm{~m}$ ) is mild and generally warm; the average annual temperature is $11.2^{\circ} \mathrm{C}$ and the average rainfall is $544 \mathrm{~mm}$ per year.

\section{Geological setting and ore-deposit mineralogy}

In the wider area of the Lojane deposit, several characteristic types of rocks have been identified, among which a serpentinite (ophiolite) and a rhyolite of Tertiary age dominate. The geological setting also comprises young granite (with numerous apophyses), Jurassic limestone, black tuff-like sandy claystone, flysch sediments, and Neogene sediments (extensive alluvial gravels to the east). The $\mathrm{Cr}$ deposit consists of several chromite lenses and layers hosted by the serpentinite. The vein- to stockwork-like hydrothermal $\mathrm{As}-\mathrm{Sb}$ (realgar and stibnite) mineralization, which is a result of the intrusion of a rhyolite body, mainly consists of steeply dipping, NW-SE trending veins (maximum thickness 3-4 m, on average 1-2 m). It extends along the contact between the rhyolite and the older, strongly silicified serpentinite, and also into the serpentinite and its chromite ores to a distance of about $0.5 \mathrm{~km}$. In addition, in the northwestern part there are insignificant stibnite occurrences, some with traces of realgar in two masses of silicified serpentinite, 100 and $400 \mathrm{~m}$ from the end of the rhyolite lens (Fig. 1). The
$\mathrm{Sb}-\mathrm{As}$ ore is very unevenly distributed in the mineralized area, such that in the area of contact with the rhyolite in the southeastern part of the deposit only $50 \%$ of the ore is located at a level of $480 \mathrm{~m}$, while the other half is in the deeper levels in the serpentinite.

After the first geological mapping studies of the area (Hiessleitner 1931, 1934, 1951, see also Schumacher 1954), which focused on the chromite deposit, fairly detailed descriptions of both geology and As-Sb ore mineralization were given by Janković (1960) and Radusinović (1966). A comprehensive study of the geology, tectonic structure, and genesis of the As-Sb deposit was provided by Antonović (1965). $\mathrm{He}$ observed ore textures reflecting the low-temperature and tectonized character of the mineralization (e.g., dolomite veins with realgar, chalcedony gangue, breccias, microbreccias, collomorphic ore types, spherulitic stibnite, and stibnite replaced by realgar). The only subsequent studies are those of Grafenauer (1977), who focused on the chromite deposit, and Augé et al. (2017), who reported on some platinumgroup minerals detected in the ophiolite-hosted chromite ore.

It should be emphasized that the rhyolites were defined differently by different authors. Namely, they have been described as porphyries (Gripp 1922), as andesite (Hiessleitner 1934, 1951, Serafimovski 1993), and as dacite (Tućan 1936), while according to Divljan (1957) these rocks are mainly rhyolites; only small 
intruded bodies within the Lojane granites were defined as dacite.

The main ore minerals observed by Janković (1960) and Antonović (1965) were sulfides of As and $\mathrm{Sb}$ (realgar, stibnite, rare orpiment), but $\mathrm{Ni}$ bearing pyrite $\left[(\mathrm{Fe}, \mathrm{Ni}, \mathrm{Co}) \mathrm{S}_{2}\right]$, vaesite $\left(\mathrm{NiS}_{2}\right)$, cattierite $\left(\mathrm{CoS}_{2}\right)$, kermesite $\left(\mathrm{Sb}_{2} \mathrm{~S}_{2} \mathrm{O}\right)$, pyrite, marcasite, molybdenite, and "pitchblende" (uraninite) were also reported to occur in minor quantities. The gangue consists of fine-grained quartz and minor dolomite. As shown by our re-study of the Lojane deposit, which started in 2016, some oxidation of the primary ore phases has resulted in the formation of secondary oxides, hydroxides, sulfates, and arsenates. Our latest findings by SEM-EDX, EPMA, Raman spectroscopy, and single-crystal and powder XRD (Đorđević et al. 2017, 2018, Kolitsch et al. 2018) proved the presence of (in alphabetical order) the following minerals: albite, alunogen, annabergite, aragonite, arsenic, baryte, chalcopyrite, coffinite, duranusite, epidote, eulytine, fluorapatite, galena, gersdorffite (previously overlooked, but fairly common according to our results), hercynite, hexahydrite, hörnesite (the predominant secondary arsenate on weathered ore specimens), hydromagnesite, hydroxylapatite, kaňkite, kaolinite-group representatives, laurite, "limonite", magnesite, magnesiochromite, magnetite, maucherite(?), millerite, monazite-(Ce), muscovite to illite, naldrettite(?), parkerite(?), pentlandite, pickeringite, polydymite(?), pyrrhotite, roméite-group minerals, rozenite, rutile, scorodite, senarmontite, spinel, stibiconite, Asbearing sulfur, tripuhyite(?), As-rich ullmannite, uvarovite, valentinite, violarite, and an unnamed $\mathrm{Bi}$ As-S-Cl(-O?) phase. Investigations of the complex primary mineralogy of both realgar-stibnite and chromite ore mineralizations are ongoing.

\section{Materials And Methods}

The preliminary sampling and documentation of the realgar-rich flotation tailings (Fig. 2a) were undertaken for the first time in November 2016 (cold and rainy period). Four samples weighing $c a$. 500-600 $\mathrm{g}$ each (labeled 6a-6d) were taken from the subsurface (to a depth of $10 \mathrm{~cm}$ at which point the samples were already very wet) from an ellipsoid-shaped hole (ca. $2 \times 3 \mathrm{~m}$ in area, depth approx. 1.5-1.7 $\mathrm{m}$ ) in the northern end of the flotation dump, where the runoff water collects (Fig. 2b). These representative samples, studied in detail (see below), differ clearly from each other with respect to their color, consistency (depend- ing on the number of secondary phases cementing individual grains and aggregates), porosity, and bulk morphology (Fig. 2c and d). The wetter and the darker the tailings, the more reduced conditions are assumed to have been during the sampling time.

Further samples along the profile (Fig. 2e) were collected in May 2017 (dry period) and were analyzed using powder X-ray diffraction and partly by Raman spectroscopy. However, these additional samples did not show any notable differences (by comparison to the above four samples) in chemical and mineralogical compositions, except for the presence of arsenolite (PXRD, Raman) as well as alunogen and Ni- and Febearing pickeringite (Raman, EDX) in the surface part of the profile.

Some minerals were separated with a binocular microscope and identified by single X-ray diffraction (SXRD) using a Nonius KappaCCD four-circle singlecrystal diffractometer (Mo tube, graphite monochromator, CCD area detector), equipped with a $300 \mu \mathrm{m}$ diameter capillary-optics collimator (Institut für Mineralogie und Kristallographie, University of Vienna).

The samples selected for powder X-ray diffraction (PXRD) were homogenized and powdered by fine grinding in an agate mortar. Homogeneous powders of all four samples were analyzed with a Bruker D8 Advance diffractometer $(\theta-\theta$ type with scintillation counter) under the following conditions (Institut für Mineralogie und Kristallographie, University of Vienna): $\mathrm{Cu} K \alpha$ radiation, position-sensitive Lynxeye detector, 40 $\mathrm{kV}, 25 \mathrm{~mA}$, step scanning in the angular range of $5^{\circ}$ to $85^{\circ} 2 \theta$ at room temperature. The step size was set to $0.01^{\circ} 2 \theta$ and dwell time to $1 \mathrm{~s}$ per step. DIFFRAC.EVA software, version 4.2, and the ICDD powder diffraction file PDF-2 were used for peak and phase identification. Using the program TOPAS (Bruker 2017), we refined the fractions of the individual minerals by the Rietveld method (supplementary material ${ }^{1}$, Fig. Sl).

Raman spectra of the polished sections (embedded in resin) were measured with a Horiba LabRam-HR system equipped with an Olympus BX41 optical microscope in the spectral range between 100 and $4000 \mathrm{~cm}^{-1}$ (Institut für Mineralogie und Kristallographie, University of Vienna). The $632.8 \mathrm{~nm}$ excitation line of a $\mathrm{He}-\mathrm{Ne}$ laser was focused with a $50 \times$ or $100 \times$ objective (N.A. $=0.90$ ) on the randomly oriented crystals and aggregates. The spectra were acquired with a nominal exposure between 10 and $60 \mathrm{~s}$ (confocal mode, 1800 lines $/ \mathrm{mm}, 1.5 \mu \mathrm{m}$ lateral resolution, and approximately $3 \mu \mathrm{m}$ depth resolution). The density of the laser power was adjusted depending

\footnotetext{
1 Supplementary Data are available from the Depository of Unpublished data on the MAC website (http:// mineralogicalassociation.ca/), document "Realgar-rich tailings, CM57, 1800074".
} 
on the mineral measured and to avoid possible sample changes due to intense laser-light absorption and resulting temperature increase.

Chemical compositions and micromorphologies of mineral phases were studied using carbon-coated polished samples or loose crystals and crystal aggregates with a JEOL JSM-6610 LV scanning electron microscope (SEM) with a W filament (15 $\mathrm{kV}$ ), equipped with an energy-dispersive X-ray (EDX) detector (Bruker e-FlashHR+, resolution $127 \mathrm{eV}$ ) and Bruker Esprit 2.0 software (Natural History Museum, Vienna).

Chemical information was obtained by employing electron energy loss spectrometry (EELS) coupled with transmission electron microscopy (TEM). For this purpose, a FEI TECNAI F20 instrument, which is equipped with a GATAN GIF Tridiem energy filter and an EDAX APOLLO XII EDX detector, was used. Data treatment was done using DigitalMicrograph ${ }^{\mathrm{TM}}$ software. The EELS measurements were conducted in scanning mode with a spatial resolution of $0.7 \mathrm{~nm}$. Quantitative chemical analysis using EELS and/or EDX has $10 \%$ relative error due to spectral noise. SAED was performed by inserting a $120 \mathrm{~nm}$ aperture in the image plane of the objective lens and parallel illumination conditions.

Major and trace element concentrations in the four selected tailings samples were determined by quadrupole ICP-MS (Agilent 7900) and ICP-OES (Perkin Elmer Optima 5300 DV) in the Department of Environmental Geosciences at the University of Vienna. The milled and homogenized samples were pressure-digested at $225{ }^{\circ} \mathrm{C}$ in a mixture of $3 \mathrm{~mL}$ of $30 \%$ suprapure hydrochloric acid $(\mathrm{HCl}), 1 \mathrm{~mL}$ of $65 \%$ suprapure nitric acid $\left(\mathrm{HNO}_{3}\right)$, and $1 \mathrm{~mL}$ of $40 \%$ suprapure hydrofluoric acid (HF) in polytetrafluoroethylene (PTFE) vessels using a Pico Trace DAS acid digestion system, following the protocols of Alexander (2008) and Dulski (2001). When the decomposition of the samples was complete, all acid mixtures were evaporated to incipient dryness and redissolved in 5 $\mathrm{mL}$ of $65 \%$ suprapure $\mathrm{HNO}_{3}$. This step was repeated twice before the samples were taken up in $2 \%$ suprapure $\mathrm{HNO}_{3}$ and analyzed by ICP-MS and ICPOES. To ensure data quality the certified reference material IF-G was also pressure-digested and analyzed for major and trace elements.

Groundwater and soil materials were sampled in 2012 as part of the "NATO-Science for Peace" project involving two of the co-authors from North Macedonia (GT and TS). These samples were taken from the immediate vicinity of the villages of Lojane and Vaksince. Details of sampling and laboratory measurements are given in Alderton et al. (2014). Measured concentrations of $\mathrm{As}$ and $\mathrm{Sb}$ in soils and waters were compared to various national reference guidelines to assess their significance. There is some variation in the values for these guidelines and the data for $\mathrm{Sb}$ are not as comprehensive as those for $\mathrm{As}$ (Alderton et al. 2014, Tasev et al. 2017). This is because the values may be set for local conditions, but also because they have been derived using different ecotoxicological tests or for different applications (e.g., drinking water, irrigation, environmental wellbeing, intervention).

\section{Chemical Composition of the Tailings}

Major and trace element concentrations of the mine tailings are shown in Table 1 . The rare earth element concentrations are given in the supplementary material (Table S1). The analyzed samples show very high concentrations of $\mathrm{Cr}, \mathrm{Ni}, \mathrm{As}$, and $\mathrm{Sb}$. In particular, arsenic concentrations range from 223 to $345 \mathrm{~g} / \mathrm{kg}$ (median $268 \mathrm{~g} / \mathrm{kg}$ As) and antimony concentrations range from 80.8 to $114 \mathrm{~g} / \mathrm{kg}$ (median $98 \mathrm{~g} / \mathrm{kg} \mathrm{Sb}$ ). Furthermore, the concentrations range from 632 to 796 $\mathrm{mg} / \mathrm{kg}$ for $\mathrm{Cr}$ (median $737 \mathrm{mg} / \mathrm{kg} \mathrm{Cr}$ ) and from 103 to $5640 \mathrm{mg} / \mathrm{kg}$ for Ni (median $1884 \mathrm{mg} / \mathrm{kg} \mathrm{Ni}$ ). Samples 6a $(5640 \mathrm{mg} / \mathrm{kg} \mathrm{Ni})$ and 6c $(3628 \mathrm{mg} / \mathrm{kg} \mathrm{Ni})$ show remarkably higher $\mathrm{Ni}$ concentrations compared to samples $6 \mathrm{~b}(140 \mathrm{mg} / \mathrm{kg} \mathrm{Ni})$ and $6 \mathrm{~d}(103 \mathrm{mg} / \mathrm{kg} \mathrm{Ni})$. Thallium was not detected, casting some doubt on the results of Janković (1989).

Random 'grab' samples from the piles of abandoned concentrate material at the Lojane smelter site were previously sampled by Alderton et al. (2014). The locations of their soil samples 22 and 23 are close to those for our tailings samples $6 \mathrm{a}$ to $6 \mathrm{~d}$. While soil samples 22 and 23 from Alderton et al. (2014) showed higher concentrations of $\mathrm{CaO}, \mathrm{Fe}_{2} \mathrm{O}_{3}, \mathrm{MgO}$, and $\mathrm{MnO}$, the tailings samples show remarkably higher concentrations for $\mathrm{Ti}$, $\mathrm{As}$, and $\mathrm{Sb}$, indicating a stronger environmental impact factor.

\section{Chemical composition of the groundwater}

The groundwater samples collected from the immediate vicinity of the flotation tailings (samples 18, 19, 20; see Fig. 3) showed an alkaline character, $\mathrm{pH}$ from 8.0 to 8.3 (Alderton et al. 2014), and elevated electric conductivities $(>700 \mu \mathrm{S} / \mathrm{cm})$. This is in accordance with the dominant lithology, mainly serpentinite (containing abundant $\mathrm{Mg}$ silicates; Hiessleitner 1934, 1951, Schumacher 1954, Tasev et al. 2017) as well as dolomite/limestone (Alderton et al. 2014).

In the sampled groundwaters, directly or intermediately influenced by the presence of mineralization, waste dump, and flotation tailings, the concentrations of arsenic ranged from 54.6 to $402 \mathrm{mg} / \mathrm{kg}$ As (median 
TABLE 1. MAJOR AND TRACE ELEMENT CONCENTRATIONS OF TAILINGS SAMPLES $6 \mathrm{a}$ TO $6 \mathrm{~d}$ AND THE CERTIFIED REFERENCE MATERIAL IF-G*

\begin{tabular}{|c|c|c|c|c|c|c|c|c|}
\hline & \multirow[b]{2}{*}{ Unit } & \multicolumn{4}{|c|}{$\begin{array}{l}\text { Chemical composition } \\
\text { of the tailings samples }\end{array}$} & \multirow[b]{2}{*}{ CRM IFG } & \multirow[b]{2}{*}{ LLoD** } & \multirow[b]{2}{*}{ Unit } \\
\hline & & $6 a$ & $6 b$ & $6 c$ & $6 d$ & & & \\
\hline $\mathrm{Al}_{2} \mathrm{O}_{3}$ & wt.\% & 2.50 & 1.09 & 2.92 & 1.02 & 0.13 & 50 & $\mu \mathrm{g} / \mathrm{kg}$ \\
\hline $\mathrm{CaO}$ & wt.\% & 6.19 & 4.84 & 5.30 & 0.71 & 1.66 & 50 & $\mu \mathrm{g} / \mathrm{kg}$ \\
\hline $\mathrm{Fe}_{2} \mathrm{O}_{3}$ & wt.\% & 3.81 & 3.68 & 3.55 & 2.46 & 57.9 & 50 & $\mu \mathrm{g} / \mathrm{kg}$ \\
\hline $\mathrm{K}_{2} \mathrm{O}$ & wt.\% & 0.55 & 0.12 & 0.37 & 0.12 & 0.018 & 20 & $\mu \mathrm{g} / \mathrm{kg}$ \\
\hline $\mathrm{MgO}$ & wt.\% & 1.98 & 0.21 & 1.77 & 0.34 & 2.02 & 20 & $\mu \mathrm{g} / \mathrm{kg}$ \\
\hline $\mathrm{MnO}$ & wt.\% & 0.067 & 0.001 & 0.050 & 0.002 & 0.042 & 5 & $\mu \mathrm{g} / \mathrm{kg}$ \\
\hline $\mathrm{Na}_{2} \mathrm{O}$ & wt.\% & 0.11 & 0.022 & 0.088 & 0.027 & 0.014 & 20 & $\mu \mathrm{g} / \mathrm{kg}$ \\
\hline $\mathrm{Li}$ & $\mathrm{mg} / \mathrm{kg}$ & 12.7 & 7.16 & 23.8 & 6.01 & 0.144 & 15.3 & $\mu \mathrm{g} / \mathrm{kg}$ \\
\hline$P$ & $\mathrm{mg} / \mathrm{kg}$ & 172 & 347 & 89.2 & 49.6 & 70.2 & 5 & $\mu \mathrm{g} / \mathrm{kg}$ \\
\hline Sc & $\mathrm{mg} / \mathrm{kg}$ & 2.30 & 1.74 & 3.98 & 1.54 & 0.205 & 12.2 & $\mu \mathrm{g} / \mathrm{kg}$ \\
\hline $\mathrm{Ti}$ & $\mathrm{mg} / \mathrm{kg}$ & 461 & 294 & 491 & 303 & 21.2 & 5 & $\mu \mathrm{g} / \mathrm{kg}$ \\
\hline $\mathrm{Cr}$ & $\mathrm{mg} / \mathrm{kg}$ & 792 & 632 & 796 & 682 & $<$ LLoD & 10 & $\mu \mathrm{g} / \mathrm{kg}$ \\
\hline $\mathrm{Ni}$ & $\mathrm{mg} / \mathrm{kg}$ & 5640 & 140 & 3628 & 103 & 23.6 & 5 & $\mu \mathrm{g} / \mathrm{kg}$ \\
\hline As & $\mathrm{g} / \mathrm{kg}$ & 232 & 303 & 223 & 345 & $<$ LLoD & 10 & $\mu \mathrm{g} / \mathrm{kg}$ \\
\hline $\mathrm{Sb}$ & $\mathrm{g} / \mathrm{kg}$ & 114 & 80.8 & 89.7 & 105 & $<$ LLod & 10 & $\mu \mathrm{g} / \mathrm{kg}$ \\
\hline Co & $\mathrm{mg} / \mathrm{kg}$ & 176 & 6.67 & 186 & 4.07 & 3.32 & 1.04 & $\mu \mathrm{g} / \mathrm{kg}$ \\
\hline $\mathrm{Rb}$ & $\mathrm{mg} / \mathrm{kg}$ & 24.2 & 9.29 & 25.4 & 8.18 & 0.284 & 2.74 & $\mu \mathrm{g} / \mathrm{kg}$ \\
\hline $\mathrm{Sr}$ & $\mathrm{mg} / \mathrm{kg}$ & 78.0 & 22.8 & 65.4 & 8.29 & 3.43 & 6.32 & $\mu \mathrm{g} / \mathrm{kg}$ \\
\hline Cs & $\mathrm{mg} / \mathrm{kg}$ & 12.0 & 22.7 & 24.1 & 22.6 & 0.059 & 0.339 & $\mu \mathrm{g} / \mathrm{kg}$ \\
\hline W & $\mathrm{mg} / \mathrm{kg}$ & 25.8 & 34.6 & 61.8 & 34.3 & 0.57 & 10.2 & $\mu \mathrm{g} / \mathrm{kg}$ \\
\hline $\mathrm{Pb}$ & $\mathrm{mg} / \mathrm{kg}$ & 23.5 & 22.7 & 28.9 & 18.6 & 5.42 & 3.85 & $\mu \mathrm{g} / \mathrm{kg}$ \\
\hline Th & $\mathrm{mg} / \mathrm{kg}$ & 1.08 & 0.79 & 2.06 & 0.54 & 0.054 & 1.36 & $\mu \mathrm{g} / \mathrm{kg}$ \\
\hline U & $\mathrm{mg} / \mathrm{kg}$ & 19.3 & 36.6 & 38.5 & 22.9 & 0.017 & 0.320 & $\mu \mathrm{g} / \mathrm{kg}$ \\
\hline
\end{tabular}

*Values for the REE are given in the supplementary material (Table S1).

** The lower limit of detection $(<L L O D)$ values are based on $(3 \times S D+$ average value of the Picotrace blank) of the respective element.

$175.7 \mathrm{mg} / \mathrm{kg} \mathrm{As})$, while the values for antimony ranged from 5.7 to $166.3 \mathrm{mg} / \mathrm{kg} \mathrm{Sb}$ (median $60 \mathrm{mg} / \mathrm{kg}$ $\mathrm{Sb})$. For all samples there is a close positive correlation between As and $\mathrm{Sb}$ (correlation coefficient 0.999). There appears to be no major variation in concentration of either As or $\mathrm{Sb}$ with $\mathrm{pH}$ (Alderton et al. 2014). In all of the water samples As concentrations exceed the $10 \mu \mathrm{g} / \mathrm{L}$ value accepted for safe drinking water (UK standard) and the stricter $5 \mu \mathrm{g} / \mathrm{L}$ MDK value (North Macedonian standard). Contrary to that, two of three Sb concentrations are lower than $10 \mu \mathrm{g} / \mathrm{L}$ and are within the acceptable limits for this element. Waters sampled from position 19 (from Vaksince in particular) showed contents of As and Sb that are well above the drinking water limits set by the various regulatory agencies. Here we would like to stress that, besides the anthropogenic influences of the former mining activities, increased concentrations of As are also the result of a high natural local geochemical background of this element, and all wells drilled in serpentine are naturally contaminated (Alderton et al. 2014, Đorđević et al. 2017, Tasev et al. 2017, Đorđević et al. 2018), and even in the zones considered not to be affected by the former mining activities, similar concentrations were detected (Alderton et al. 2014).

\section{Chemical compositions of the soil samples}

Three samples of soil from locations separate from the mine dumps exhibit very high concentrations of arsenic from 81 to $1611 \mathrm{mg} / \mathrm{kg} \mathrm{As}$ (median $1009 \mathrm{mg}$ / $\mathrm{kg}$ ) and antimony from 35 to $749 \mathrm{mg} / \mathrm{kg} \mathrm{Sb}$ (median $605 \mathrm{mg} / \mathrm{kg}$ ). As we assumed, sampling point 23, in the immediate vicinity of the flotation tailings, is particularly conspicuous with its high arsenic and antimony values (As $>1600 \mathrm{mg} / \mathrm{kg}$ and $\mathrm{Sb}>749 \mathrm{mg} / \mathrm{kg}$ ). Measured Mo and $\mathrm{Tl}$ values are also particularly high in that sample. All three soil samples have As and $\mathrm{Sb}$ contents which exceed proposed environmental quality limits (typically around $20 \mathrm{mg} / \mathrm{kg}$ for both elements), and even if a rather conservative threshold value of 50 $\mathrm{mg} / \mathrm{kg}$ for both $\mathrm{Sb}$ and As is adopted, it is clear that many samples have contents of these elements which are above the 'intervention' values and are thus classed 

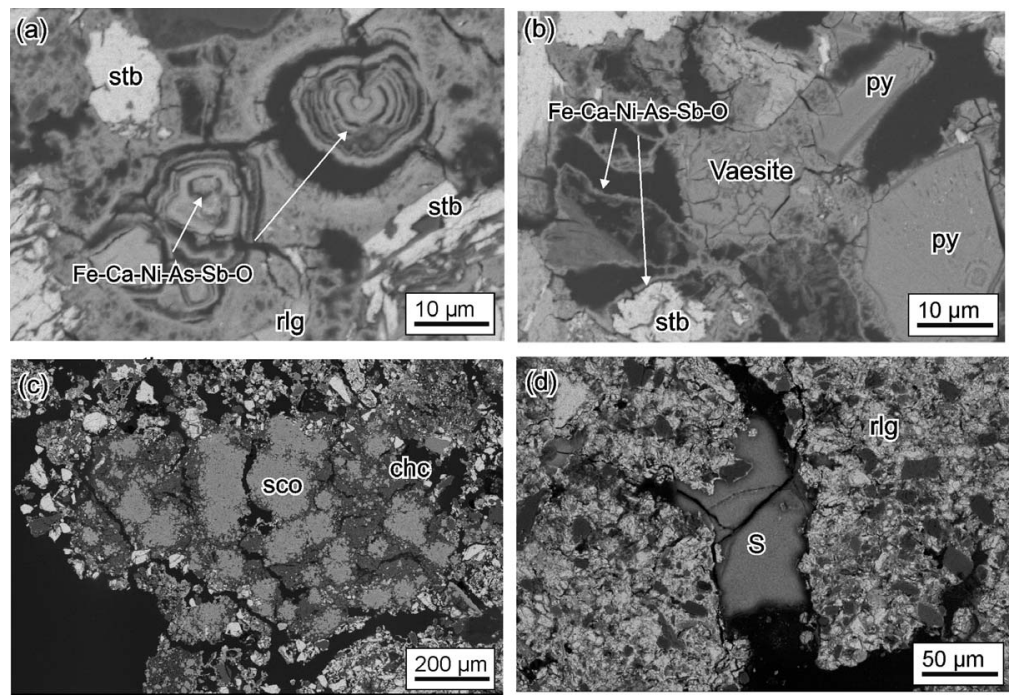

FIG. 4. Back-scattered electron images of tailings samples 6a and 6b. (a) Concentrically layered aggregates of an Fe-Ca-As-Sb$\mathrm{O}(\mathrm{OH})$ phase in 6a. (b) Fractured vaesite $\left(\mathrm{NiS}_{2}\right)$ grains with pyrite (py) and stibnite (stb) crystals together with thin crusts of an Fe-Ca-As-Sb-O(OH) phase in 6a. (c) Overview showing massive and spherulitic scorodite (sco) and chalcedony (chc) with grains of quartz (dark) and realgar (bright) in 6b. (d) As-bearing sulfur (S) in realgar (rlg) in 6b.

as 'contaminated' and requiring remediation (Alderton et al. 2014, Tasev et al. 2017). In addition, these results are similar to those found for comparable abandoned mine sites elsewhere (Gal et al. 2007, Drahota \& Filipi 2009, Alloway 2013). As mentioned earlier, there is a notable influence of the serpentinite on the samples, which is especially illustrated by high concentrations of $\mathrm{Mg}, \mathrm{Cr}$, and $\mathrm{Ni}$ in all three soil samples ( $\mathrm{MgO}$ up to $18.32 \mathrm{wt} \%$, Cr up to $438 \mathrm{mg} / \mathrm{kg}$, Ni up to $1119 \mathrm{mg} / \mathrm{kg}$; Alderton et al. 2014). Statistical analysis performed on the soil compositions show that the highest correlation coefficients, as expected, occur for As-Sb (0.9781), As-Mo (0.9641), Sb-Mo (0.9982), Ni-Cr (0.9751), $\mathrm{Pb}-\mathrm{Cr}(0.9302)$, and $\mathrm{Pb}-\mathrm{Ni}$ (0.8258).

\section{Mineralogy of the TAILINGS}

The cemented, porous, realgar-rich waste material was found to be a fine-grained mixture of the preweathering minerals (primary sulfides, mostly realgar) which were present in the tailings at the time of the deposition and their weathering products. According to the SEM studies of the polished samples, the grain size varies from $<0.1$ to (rarely) $250 \mu \mathrm{m}$. The average grain size is estimated to vary between 20 and $100 \mu \mathrm{m}$. In comparison to the most abundant pre-weathering minerals, such as realgar, stibnite, chromite, gypsum, and quartz, which could be easily distinguished using a binocular microscope, the weathering minerals were not easily recognized during preliminary investigations. This could be attributed to the small crystal size of the fine-grained material and the fact that these minerals formed via subrecent to recent weathering processes (the samples were collected from the surface and sub-surface of the tailings dump). Detailed descriptions of the studied samples and the list of identified minerals, including the methods used for their identification, are given in Table 2. Powder X-ray diffraction (PXRD) patterns with the results of their Rietveld analysis are presented in Figure S1 in the supplementary material. Selected SEM images are given in Figures 4 and 5, while selected Raman spectra are shown in Figure 6 and TEM images in Figure 7.

\section{Primary minerals}

The primary sulfide minerals realgar and stibnite are common in all analyzed samples. The same applies to quartz and gypsum (Table 2). In general, the main minerals in the tailings are realgar, gypsum, and quartz (Fig. 4), whereas stibnite is less abundant.

The two AsS polymorphs realgar and pararealgar represent the most abundant phases in all samples (average: $\sim 55$ wt.\% per sample) and their presence was proven by all experimental methods. The SEMEDX analyses of the polished sections showed that the majority of the tailings material consists of realgar fragments about $50-150 \mu \mathrm{m}$ in size, which in samples $6 \mathrm{a}$ and $6 \mathrm{c}$ are invariably coated by very thin crusts of 


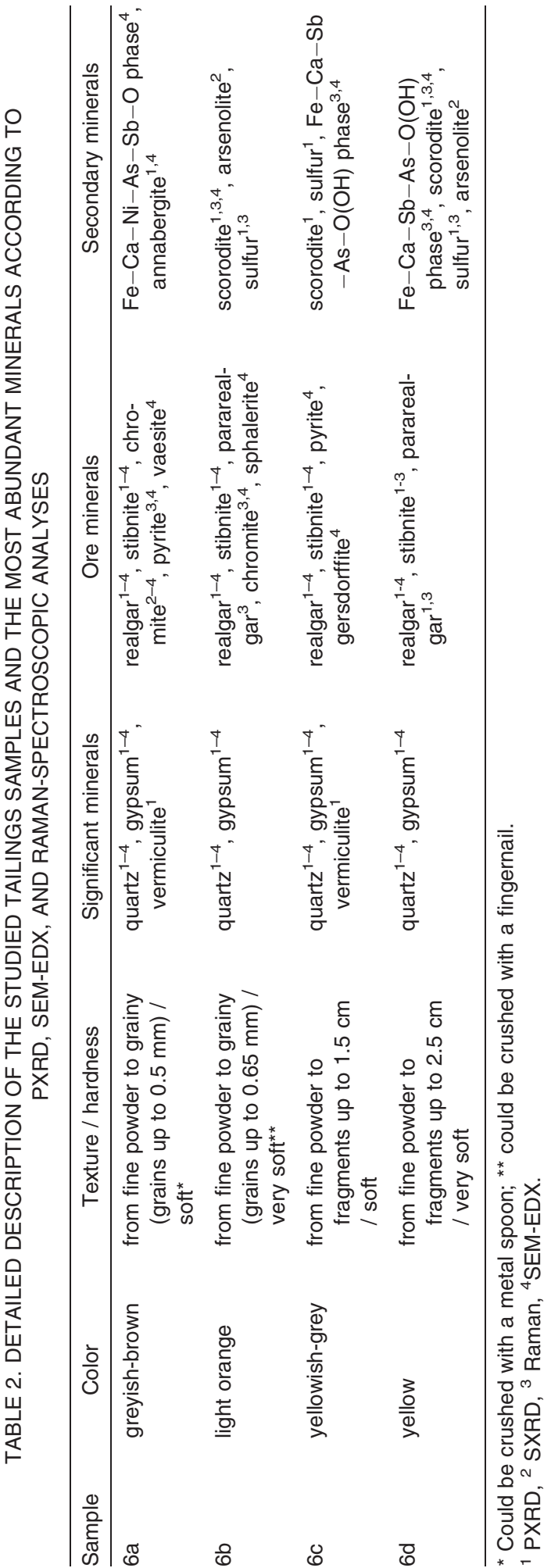

an As-Sb-Ca-Fe-(Ni)-oxide/hydroxide (Figs. 4 and 5). However, the size of the individual realgar grains can be less than $2 \mu \mathrm{m}$, but also up to $0.5 \mathrm{~mm}$. The realgar is nearly always pure, with an As:S ratio near to 1 , although some grains contain traces of $\mathrm{Sb}$ substituting for As. The color depends on the size; small grains show an orange color while larger grains appear red.

Stibnite occurs in the form of superficially corroded grains between 1 and $100 \mu \mathrm{m}$ in size, partly embedded in either quartz or realgar. Stibnite is the second most abundant sulfide in the tailings. It is chemically either almost pure (samples 6a, 6b, and 6d) or it contains arsenic up to 4.8 at.\% (sample $6 \mathrm{c}$ ).

Rare relic Mg-rich chromite grains (up to $\sim 20 \mu \mathrm{m}$ ) and, less commonly, magnesiochromite are always Albearing (7.8-14.4 at.\%) and occur as anhedral, unaltered crystal fragments which are chemically homogeneous but show minor variations in the $\mathrm{Cr}: \mathrm{Al}$ and $\mathrm{Fe}: \mathrm{Mg}$ ratios among different grains. Chromite was found in all samples, except sample $6 \mathrm{c}$.

Tiny euhedral to anhedral pyrite crystals (up to $\sim 7$ $\mu \mathrm{m})$ are very rare and are found in samples $6 \mathrm{a}$ and $6 \mathrm{c}$. They are always As-bearing (up to 2.2 at. $\%$ of As in $6 \mathrm{a}$ and up to 5 at.\% in $6 \mathrm{c}$ ). Pyrite from sample 6 a contains trace amounts of $\mathrm{Ni}$ (up to 1.5 at.\%). A few gersdorffite grains up to $5 \mu \mathrm{m}$ are found in realgar (sample 6a) and quartz (6c). Vaesite $\left(\mathrm{NiS}_{2}\right)$ has been identified as inclusions in realgar (sample 6a) in the form of patchy aggregates (up to $\sim 10 \mu \mathrm{m}$ ). One very small grain $(\sim 2 \mu \mathrm{m})$ of sphalerite embedded in quartz was found in sample $6 b$.

As representatives of the gangue minerals and country rocks, quartz (chalcedony), clay minerals (kaolinite-illite-vermiculite), muscovite, albite, fluorapatite, anatase/rutile, and epidote have been identified. Among these, quartz is very abundant (on average $\sim 18.7$ wt. $\%$ per sample), whereas the other minerals appear only as minor to trace components.

\section{Secondary minerals}

Secondary minerals in the tailings include gypsum, As-Sb-Ca-Fe-(Ni)-O(OH) roméite-group minerals, scorodite, arsenolite, pararealgar, native sulfur, annabergite, unidentified sulfo-arsenates, "limonite", kaatialaite(?), pickeringite, and alunogen. The last two phases were not detected in samples $6 \mathrm{a}-6 \mathrm{~d}$ but were found only on the profile walls and during sampling in the dry period (Fig. 2e).

Gypsum, $\mathrm{CaSO}_{4} \cdot 2 \mathrm{H}_{2} \mathrm{O}$, is the most abundant weathering phase. According to the Rietveld analyses, its amount ranges between 4.5 and 17.5 wt.\%, depending on the sample. It is mostly present as white coatings formed by prismatic to needle-like single crystals up to $250 \mu \mathrm{m}$ in length occurring on realgar. 

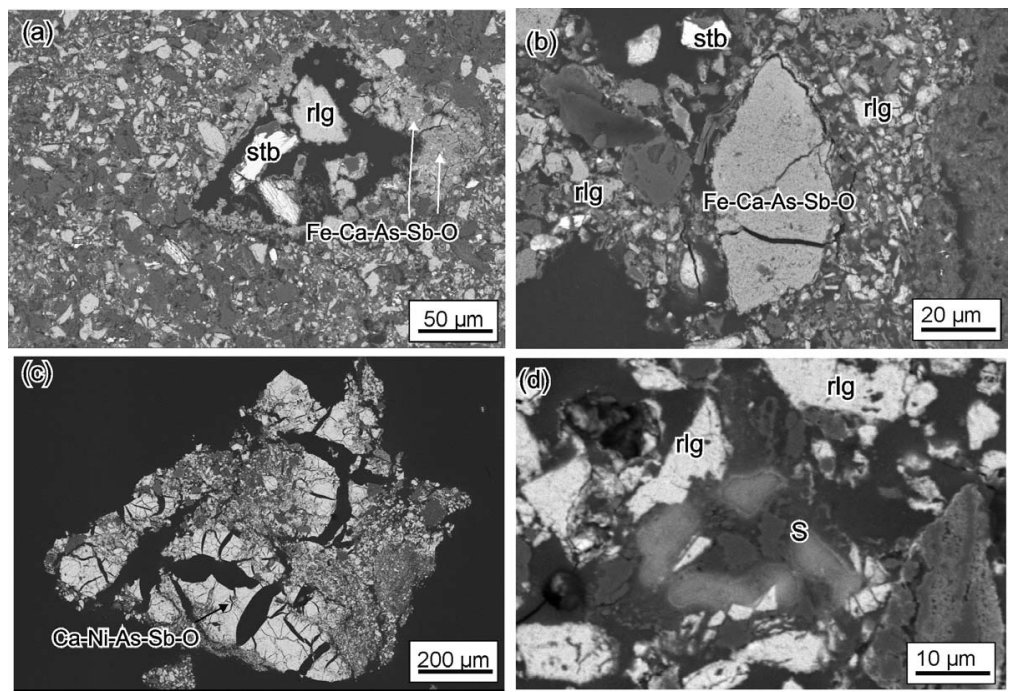

FIG. 5. Back-scattered electron images of samples $6 \mathrm{c}$ and $6 \mathrm{~d}$. (a) Recently grown Fe-Ca-As-Sb-O $(\mathrm{OH})$ phase at the rims of the void in 6c. (b) $60 \mu \mathrm{m}$ grain of an Fe-Ca-As-Sb-O $(\mathrm{OH})$ phase in 6c. (c) Overview showing crack-like texture of the Ca-Ni$\mathrm{Sb}-\mathrm{As}-\mathrm{O}(\mathrm{OH})$ phase, suggesting a prior gel state in 6d. (d) Sulfur (S) and realgar (rlg) in 6d.

Together with other sulfates (see below), it is the youngest mineral in this mineral assemblage. The EDX analyses reveal trace contents of $\mathrm{As}\left(\mathrm{AsO}_{4}\right.$ replacing $\mathrm{SO}_{4}$ ).

Pararealgar, AsS, represents the only secondary sulfide observed in the tailings and was detected in samples $6 \mathrm{~b}$ and $6 \mathrm{~d}$ (both having light orange color) by Raman spectroscopy and in sample $6 \mathrm{~d}$ by PXRD. In sample $6 \mathrm{~d}$ it is the dominant phase ( $40 \mathrm{wt} . \%)$, whereas in sample $6 \mathrm{~b}$ only minor amounts of pararealgar were found (Raman). It forms as a typical light-induced isochemical alteration product of realgar and is easily recognizable as an orange, thin, and finegrained coating on any realgar lying on the tailings surface (as well as on weathered ore dumps; Kolitsch et al. 2018). Thus, the orange color of the surface of the tailings dump is due to the formation of pararealgar (Fig. 2a). The Raman spectrum of pararealgar is characterized by a pair of strong peaks at 221 and 232 $\mathrm{cm}^{-1}$ (supplementary material, Fig. S2) and a group of four distinguishable peaks centered at about $330 \mathrm{~cm}^{-1}$ (Trentelman \& Stodulski 1996). Furthermore, the peak at $273 \mathrm{~cm}^{-1}$ appears only in pararealgar. In comparison to the Raman spectrum of realgar, the pararealgar spectrum has a greater number of bands of strong or medium intensity, reflecting the reduced molecular symmetry of pararealgar with respect to realgar.

Scorodite, $\mathrm{Fe}^{3+} \mathrm{AsO}_{4} \cdot 2 \mathrm{H}_{2} \mathrm{O}$, is the most widespread arsenate mineral in the tailings and was found in samples $6 \mathrm{~b}$ and $6 \mathrm{~d}$. It usually occurs as a cement that fills the space among the mineral grains or in the form of massive or tiny spheroidal aggregates (Fig. 6a and b). In sample $6 \mathrm{~b}$ it forms massive aggregates and in sample $6 \mathrm{~d}$ it appears only sporadically in the form of elongate aggregates up to $40 \mu \mathrm{m}$ in length that give the impression of being a former gel. The scorodite always contains traces of $\mathrm{Sb}(0.6-3.6$ at.\%), S (0.5-2.6 at.\%), and $\mathrm{Al}(0.3-3.3$ at.\%), which is also reflected in the Raman spectra (supplementary material, Fig. S3) by the appearance of two Raman bands at 464 and 527 $\mathrm{cm}^{-1}$, characteristic for the $\mathrm{Sb}^{5+}-\mathrm{O}$ antisymmetric and symmetric stretching vibrations, respectively (Bahfenne \& Frost 2010a). Other Raman bands (given in italics) correspond quite well with the Raman spectra reported for natural scorodites (Filippi et al. 2007, 2009, Kloprogge \& Wood 2017) with major bands at $\sim 180(181), \sim 799(804)$, and $\sim 893$ $(890) \mathrm{cm}^{-1}$. The very strong bands at $\sim 800$ and $\sim 900$ $\mathrm{cm}^{-1}$ are assigned to As-O stretching in scorodite (Savage et al. 2005).

Rare native sulfur was identified in PXRD patterns and by SEM-EDX in all samples except 6 a. Chemical analyses of the sulfur showed that it is always Asbearing (on average $\sim 5$ at.\%). However, a few grains with 14 at. $\%$ arsenic on average were found in sample $6 d$.

Widespread, but volumetrically small, are thin crusts of As-Sb-Ca-Fe-(Ni)-O(OH) phases (with traces of $\mathrm{S}, \mathrm{Na}, \mathrm{K}$, and $\mathrm{Al}$ ) in which the $\mathrm{As}: \mathrm{Sb}$ ratio varies from $c a .2: 1$ to $1: 2.2$ and $\mathrm{Ca}, \mathrm{Fe}$, and $\mathrm{Ni}$ contents are variable (Table 3). This generally inhomogeneous weathering product appears to be microcrystalline but 


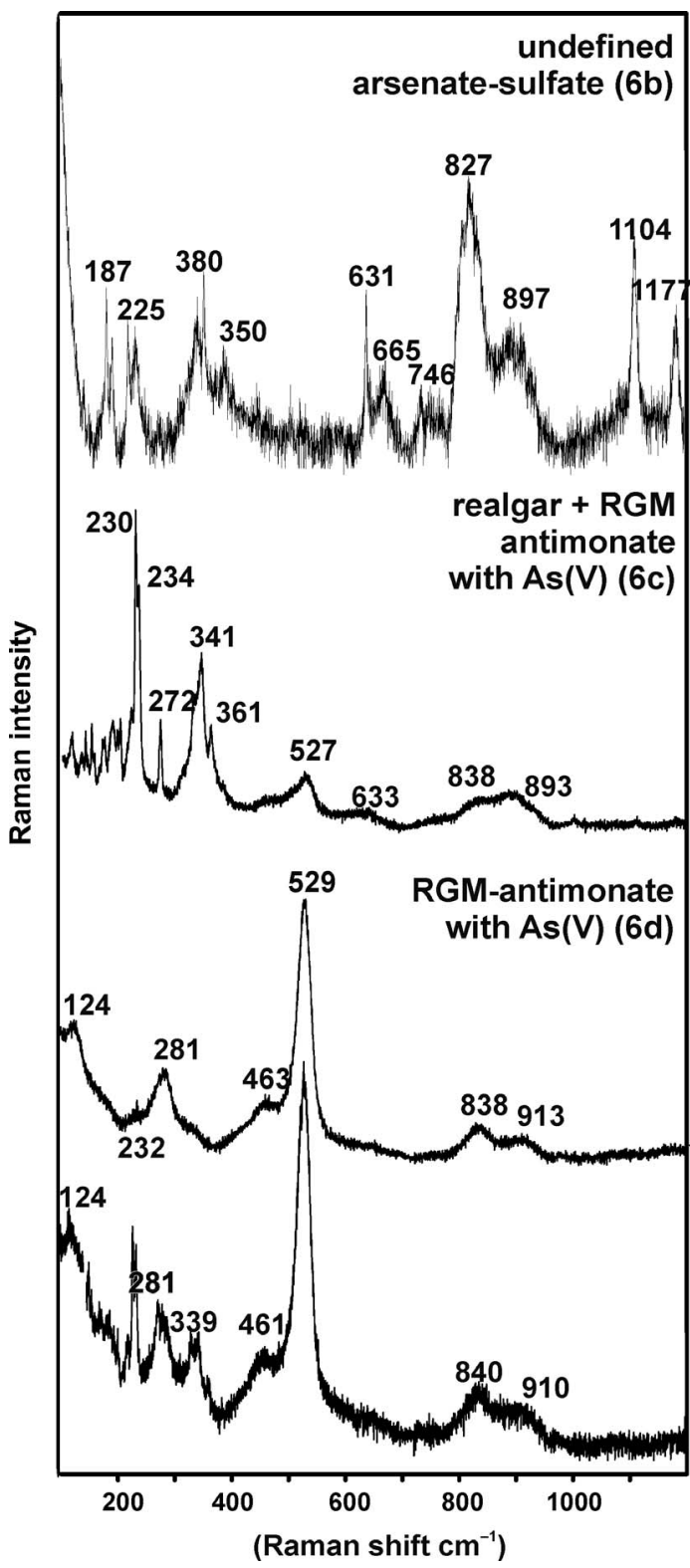

FIG. 6. Selected Raman spectra of the weathering phases ( $\mathrm{RGM}=$ roméite-group mineral).

may in part be amorphous. According to the observed stoichiometry, crystalline forms probably belong, at least in part, to the roméite group of oxides, which itself belongs to the large pyrochlore supergroup of minerals (Atencio et al. 2010, Christy \& Atencio 2013). The general formula of the pyrochlore supergroup is ${ }^{[8]} A_{2-\mathrm{m}}{ }^{[6]} B_{2} X_{6-\mathrm{w}} Y_{1-\mathrm{n}}(A=\mathrm{Na}, \mathrm{Ca}, \mathrm{Ag}, \mathrm{Mn}, \mathrm{Sr}$, $\mathrm{Ba}, \mathrm{Fe}^{2+}, \mathrm{Pb}, \mathrm{Sn}^{2+}, \mathrm{Sb}^{3+}, \mathrm{Bi}^{3+}, \mathrm{Y}, \mathrm{REE}, \mathrm{Sc}, \mathrm{U}, \mathrm{Th}$, vacancy, and $\mathrm{H}_{2} \mathrm{O} ; B=\mathrm{Ta}, \mathrm{Nb}, \mathrm{Ti}, \mathrm{Sb}^{5+}, \mathrm{W}, \mathrm{V}^{5+}, \mathrm{Sn}^{4+}$, $\mathrm{Zr}, \mathrm{Hf}, \mathrm{Fe}^{3+}, \mathrm{Mg}, \mathrm{Al}$, and $\mathrm{Si} ; X=\mathrm{O}, \mathrm{OH}$, or F; and $Y=$ $(\mathrm{OH})^{-}, \mathrm{F}^{-}, \mathrm{O}^{2-}$, vacancy, $\mathrm{H}_{2} \mathrm{O}$, or even large cations $\mathrm{K}^{+}, \mathrm{Rb}^{+}, \mathrm{Cs}^{+}$) (Bosi et al. 2017). $\mathrm{Sb}(\mathrm{V})$ is the dominant cation at the $B$ site in the roméite-group minerals (RGM). The latter have been identified as weathering products in smelting residues (CourtinNomade et al. 2012) and tailings (Klimko et al. 2011) resulting from $\mathrm{Sb}$ mining activities, and as the weathering products of tetrahedrite and tennantite (Borčinová Radková et al. 2017, Majzlan et al. 2018, Keim et al. 2018).

Besides forming very thin $(<10 \mu \mathrm{m})$ encrustations (mostly As-dominant) around realgar and stibnite grains (Fig. 4), Sb-dominant variants of this oxide also form larger homogeneous grains up to $500 \mu \mathrm{m}$, characterized by broad dehydration cracks and suggesting original formation as a gel (Figs. 7 and 8). An As-rich As-Sb-Fe-Ca-O $(\mathrm{OH})$ phase (Table 3) from sample 6c and an Sb-rich Sb-As-Fe-Ca-O $(\mathrm{OH})$ phase from sample $6 \mathrm{~d}$ were further analyzed by Raman spectroscopy (Fig. 6). The Raman spectra of both samples are most similar to the spectra of pyrochloresupergroup antimonates. Bahfenne \& Frost (2010a) analyzed Raman spectra of the mineral roméite group minerals, from three different localities. According to these authors, the intense Raman band around $\sim 520$ $\mathrm{cm}^{-1}$ is assigned to the $\mathrm{Sb}-\mathrm{O} v_{1}$ symmetric stretching mode and the band around $466 \mathrm{~cm}^{-1}$ is assigned to the $\mathrm{Sb}-\mathrm{O} v_{3}$ antisymmetric stretching mode. The Raman bands between 303 and $340 \mathrm{~cm}^{-1}$ are attributed to $\mathrm{O}$ $\mathrm{Sb}-\mathrm{O}$ bending modes. The Raman bands in these regions measured for samples $6 \mathrm{c}$ and $6 \mathrm{~d}$ correspond quite well with the literature data and thus confirm the presence of $\mathrm{Sb}^{5+}$ in these phases. Additional weaker and broader bands in the region between 835 and $915 \mathrm{~cm}^{-1}$ (Fig. 6) correspond to the $\mathrm{AsO}_{4}$ stretching vibrations (Bahfenne \& Frost 2010b, Đorđević et al. 2016) and thus confirm the presence of $\mathrm{As}^{5+}$ in the structure. Recently, unusually As-rich and $\mathrm{Cu}$-bearing roméite-group phases were described as weathering products of tetrahedrite-tennantite weathering (Borčinová Radková et al. 2017, Majzlan et al. 2018).

In order to characterize the As-Sb-Ca- $(\mathrm{Fe})-(\mathrm{Ni})-$ $\mathrm{O}(\mathrm{OH})$ phases and their crystallinity in more detail, transmission electron microscopy (TEM) investigations were performed. Two phases were determined, one amorphous and one crystalline. The amorphous phase was found to be sensitive to electron beam irradiation and consists of As and $\mathrm{S}$ (former realgar). The crystalline phases - all appear to be oxides or hydroxides - are stable under electron beam irradiation. High-resolution (HR) TEM images consistently show the presence of Fe-Sb-As oxo-hydroxide nano- 

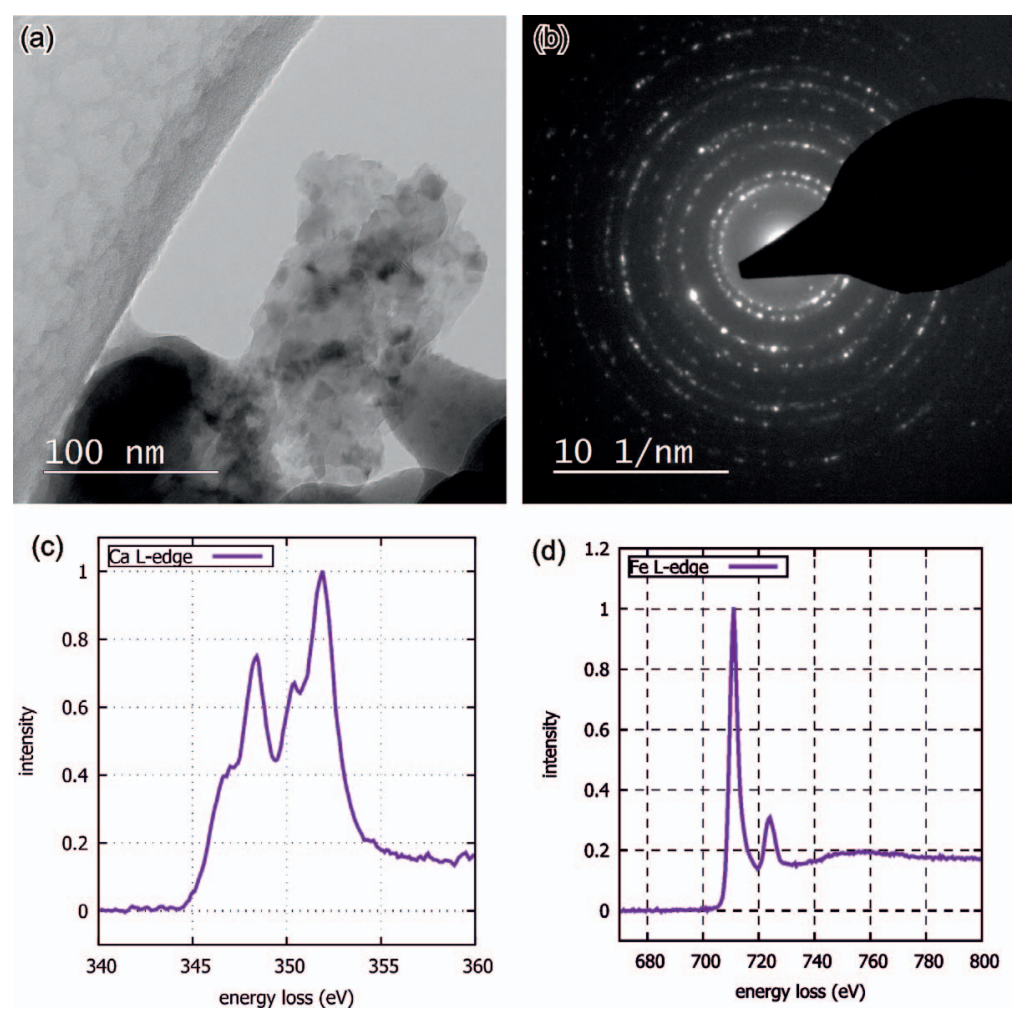

FIG 7. TEM images from tailings samples. (a) Typical particles of the roméite-group phase found in sample 6c. (b) Diffraction pattern showing the diffraction rings and a faint crystalline signature (diffraction spots). (c) Ca- $L$ edge showing the ELNES (Energy Loss Near Edge Structure) spectrum of $\mathrm{Ca}^{2+}$. (d) Fe- $L$ edge showing the ELNES spectrum of $\mathrm{Fe}^{3+}$.

TABLE 3. SEMI-QUANTITATIVE CHEMICAL ANALYSES (SEM-EDX) OF CHEMICALLY VARIABLE SECONDARY Fe-Ca-(Ni)-As-Sb-O(OH) PHASES FROM THE FLOTATION TAILINGS OF THE LOJANE MINE

\begin{tabular}{lccc}
\hline $\begin{array}{l}\text { Elements (at.\%)* } \\
\text { \# of spots }\end{array}$ & Fe-Ca-Ni-As-Sb-O(OH) & Fe-Ca-As-Sb-O(OH) & Fe-Ca-As-Sb-O(OH) \\
Sample & $n=6$ & $n=3$ & $\begin{array}{c}(\mathrm{OH}) \\
6 \mathrm{~d}\end{array}$ \\
\hline $\mathrm{O}$ & $6 \mathrm{a}$ & $57(54-61)$ & $70(68-71)$ \\
$\mathrm{Na}$ & $67(65-68)$ & $0.45(0.4-0.5)$ & - \\
$\mathrm{Al}$ & $0.5(0.3-0.6)$ & $1.7(0.7-3.3)$ & $1.1(0.3-2.1)$ \\
$\mathrm{Si}$ & - & $1.6(1.1-2.3)$ & $1.0(0.5-1.4)$ \\
$\mathrm{K}$ & $0.7(0.4-1.0)$ & - & $0.7(0.6-0.8)$ \\
$\mathrm{Ca}$ & - & $1.9(1.8-2.0)$ & $3.7(2.1-5.9)$ \\
$\mathrm{Fe}$ & $5.3(4.2-6.8)$ & $9.0(8.4-9.9)$ & $4.9(4.0-6.1)$ \\
$\mathrm{Ni}$ & $6.0(5.2-6.6)$ & - & - \\
$\mathrm{As}$ & $2.1(0.7-3.8)$ & $16.9(16.4-17.6)$ & $15.4(13.0-16.9)$ \\
$\mathrm{Sb}$ & $10.83(9.5-12.7)$ & $11.0(8.9-12.4)$ & $21.8(14.6-28.7)$ \\
\hline
\end{tabular}

* Normalized to $100 \%$; estimated accuracy of cation values is better than $3-5 \%$ for major amounts and better than $20 \%$ for trace amounts.

$n=$ number of spot analyses. 
particles (Fig. 7a). There was no truly amorphous material detected among the Fe-Sb-As-oxides in the samples. Selected-area electron diffraction (Fig. 7b) was used to document the crystallinity of these nanoparticles. Due to the fact that the $\mathrm{Ca}-K$ edge partly overlaps with the Sb- $L$ edge in the TEM-EDX analysis, EELS was used to identify Ca. Figure $7 \mathrm{c}$ presents the $\mathrm{Ca}-L$ edge at $356 \mathrm{eV}$ energy loss, clearly showing the shape characteristic of $\mathrm{Ca}^{2+}$. In the cases where iron was detected, its oxidation state was determined to be $\mathrm{Fe}^{3+}$ (Fig. 7d).

From the combination of SEM, TEM, and Raman measurements, it is likely that the analyzed thin crusts and aggregates are poorly crystalline to amorphous Asdominant RGM-like phases, darker grey in the SEM images (Fig. 5), and nano- to microcrystalline, Sbdominant RMG, which are very light grey in the SEM and Raman images. The crystallographic position of arsenic in the RGM in our samples is not fully clear. Although $\mathrm{As}^{5+}$ may occupy the octahedrally coordinated $A$ position in the roméite structure [a small number of natural and synthetic compounds containing $\mathrm{AsO}_{6}$ octahedra are known: the mineral aerugite, $\mathrm{Ni}_{8.5} \mathrm{As}_{3} \mathrm{O}_{16}$ (Fleet \& Barbier 1989) and several alkali/silver-(H)-AsO compounds (Schwendtner \& Kolitsch 2007 and references therein)], it strongly prefers a tetrahedral coordination. The distorted cubic (eight-coordinated) $B$ position in RGM is too large for the $\mathrm{As}^{5+}$ cation. These crystal-chemical preferences explain why As is hosted mainly in the X-ray amorphous phases. However, EDX point analyses, both in our work and in Majzlan et al. (2018), clearly show that the roméite-type phase may incorporate considerable arsenic.

Arsenolite, $\mathrm{As}_{2} \mathrm{O}_{3}$, was identified in PXRD patterns (samples $6 \mathrm{~b}$ and $6 \mathrm{~d}$ ). Besides being found in powdered bulk samples, arsenolite, together with the sulfates pickeringite, $\mathrm{MgAl}_{2}\left(\mathrm{SO}_{4}\right)_{4} \cdot 22 \mathrm{H}_{2} \mathrm{O}$, and alunogen, $\mathrm{Al}_{2}\left(\mathrm{SO}_{4}\right)_{3}\left(\mathrm{H}_{2} \mathrm{O}\right)_{12} \cdot 5 \mathrm{H}_{2} \mathrm{O}$, occurs as a minor phase on the surface of the profile walls. These minerals form on the surface of the tailings, probably over days and/ or weeks. Both sulfate minerals were identified by Raman spectroscopy (supplementary materials, Fig. S3) and EDX analyses. The latter revealed that the pickeringite, which occurs as silky white fibrous aggregates, is chemically fairly homogeneous and $\mathrm{Fe}$ - and $\mathrm{Ni}^{2+}$-bearing $(\mathrm{Mg}>\mathrm{Fe}>\mathrm{Ni})$, the $\mathrm{Fe}$ most probably being in part trivalent; in addition, trace amounts of As were detected. Positions and relative intensities of the Raman bands of the measured pickeringite (in parentheses in italics) correspond quite well with major bands of the Fe-bearing pickeringite $[221$ (219), 315 (314), 344 (335), $\sim 424$ (428), 468 (467), 530 (531), 621 (615), 〜976 (975), 986 (991), 995 (996), 1071 (1068), $\sim 1114$ (1115), and $\left.\sim 1145(1145) \mathrm{cm}^{-1}\right]$ reported in the literature (Locke et al. 2007). The alunogen (tiny colorless platelets) is chemically pure. Positions of the alunogen Raman bands (in parentheses in italics) and their relative intensities show good agreement with major bands reported at $\sim 156$ (156), $\sim 182$ (181), ح191 (191), 310 (308), 342 (344), 473 (471), $\sim 528$ (527), 611 (608), 992 (992), 1086 (1087), and $\sim 1127(1124) \mathrm{cm}^{-1}$ in the literature (Košek et al. 2018). Arsenolite was found in the form of very small (up to $15 \mu \mathrm{m}$ ) octahedral crystals dispersed on the surface of a gypsum crystal and as tiny, loose crystal aggregates. Raman bands of the measured arsenolite (in parentheses in italics) agree very well with major bands reported in the literature (Merrow et al. 2003): $\sim 184$ (182), 268 (266), 370 (369), and 561 (560) $\mathrm{cm}^{-1}$. Indistinct very few tiny, blocky grains of kaatialaite(?), or a chemically similar phase, were identified only by EDX.

Trace amounts of inhomogeneous iron oxyhydroxides were detected in samples $6 \mathrm{~b}$ and $6 \mathrm{~d}$. The "limonite" aggregates may contain up to 3.2 at.\% arsenic, 3.1 at.\% antimony, and up to 1.5 at.\% sulfur, among other very minor impurities, such as $\mathrm{Al}, \mathrm{Si}, \mathrm{Ca}$, and $\mathrm{Ti}$.

\section{Sulfide Weathering and the Mobility of Contaminants}

\section{Behavior of arsenic}

In contrast to the well-researched weathering of the Fe-bearing arsenic minerals, such as arsenopyrite and As-bearing pyrite (e.g., Nesbitt et al. 1995, Corkhill \& Vaughan 2009, Zhu et al. 2014), the natural weathering of Fe-free arsenic minerals, such as realgar and orpiment, is not well studied, despite their significant toxicity and their relative abundances in the environment.

In a recent study on the migration and transformation of arsenic in the realgar mining areas in China, $\mathrm{Wu}$ et al. (2017) reviewed the transformation principles and processes involving physical, chemical, and biological reactions in realgar. The results of their study showed that the migration processes lead to contamination of atmosphere, water, and soil in all realgar mining areas. However, Wu et al. (2017), like most other papers dealing with the weathering of realgar, does not answer the question of how As, Sb, and other toxic elements are hosted in the oxidation products. Instead, they focus mostly on the bulk chemical composition of the waste dumps and tailings but provide little information on the specific mineralogy and the important transformation pathways of the minerals. Only the recent mineralogical study of the As-bearing secondary minerals of the weathered oripiment-realgar tailings of the Shimen mine, China, 
by Zhu et al. (2015) deals with the mineralogical behavior of arsenic during the natural weathering of realgar and orpiment. Zhu et al. (2015) identified the As-bearing secondary minerals in the weathered tailings and used these data to discuss the natural oxidation of orpiment and realgar and associated implications for the transformation and mobility of As.

Most information about the mobility and behavior of arsenic in neutral to alkaline conditions is derived from theoretical and laboratory-based experimental work (Lengke \& Tempel 2003, 2005, Lengke et al. 2009 and references therein). From these studies we know that the oxidative dissolution rates of realgar increase with increasing $\mathrm{pH}$ values, dissolved oxygen concentrations, and temperature. For example, arsenic sulfide oxidation rates at near neutral to alkaline $\mathrm{pH}$ values are approximately three times to three orders of magnitude higher than those at $\mathrm{pH} \sim 2$.

Quantum mechanical calculations of the realgar oxidation (Renock \& Becker 2010) showed that at low $\mathrm{pH}$ (i.e., no co-adsorbing hydroxide) the paramagnetic $\left({ }^{3} \mathrm{O}_{2}\right)$ to diamagnetic $\left({ }^{1} \mathrm{O}_{2}\right)$ spin transition is the ratelimiting step of the oxidation. At high $\mathrm{pH}$, the ratelimiting step is oxygen dissociation on the surface. The theoretically calculated oxidation rate $\left(\sim 1 \times 10^{-10} \mathrm{~mol}\right.$ $\left.\mathrm{m}^{-2} \mathrm{~s}^{-1}\right)$ is of the same order as empirically derived rates from experiments at $T=298 \mathrm{~K}, \mathrm{pH}=8$, and similar dissolved oxygen concentrations.

Typically, the oxidative weathering and the light oxidation process, which proceed simultaneously, control transformation of the realgar-rich flotation tailings at Lojane. Naumov et al. (2007) found that on exposure to light, As in realgar can react with oxygen to generate $\mathrm{As}_{2} \mathrm{O}_{3}$, meaning that oxidation reactions are also involved in photo-induced conversions. Under natural conditions, photo-induced conversion would result in $\sim 5 \% \quad \mathrm{As}_{4} \mathrm{~S}_{4}, 20 \% \quad \mathrm{As}_{2} \mathrm{O}_{3}$, and $75 \%$ pararealgar (Ballirano \& Maras 2006). During this process, the As(II) in realgar directly transforms into As(III) and $\mathrm{As}(\mathrm{V})$. In the Lojane tailings, photo-induced conversion varies locally, depending on closeness to the dump surface, with up $\sim 40 \%$ of the realgar transformed into pararealgar.

In iron-rich weathering environments, the arsenate anions are usually adsorbed on oxyhydroxide phases, resulting in reduced mobilization of arsenate into the environment. However, if the concentrations of bicarbonate and carbonate are high, As can be released from the surface of the iron oxyhydroxides back to the solution because of surface charge or may also act as a competitor for both $\mathrm{As}^{5+}$ and $\mathrm{As}^{3+}$ during sorption reactions (Lengke et al. 2009). In the Lojane flotation tailings, as well as in its waste dumps (Kolitsch et al. 2018), ferric iron oxyhydroxide phases are present only in insignificant quantities. Thus, the reduced mobilization of arsenate does not happen and only the precipitation of the dissolved arsenate as minor scorodite, annabergite, arsenolite, and As-bearing RGM phases precludes its further migration into the environment.

Similar to the Lojane tailings, the mineralization and general geology around the Shimen mine in China (Zhu et al. 2015) is Fe-poor and Ca-rich and the amount of As in its tailings is very high (33.97 wt.\% As). At Shimen, the $\mathrm{pH}$ in the tailings is lower than at Lojane, and the As is generally immobilized in the form of acid $\mathrm{Ca}$ arsenates (weilite, pharmacolite), the acid $\mathrm{Ca}-\mathrm{Mg}$ arsenate picropharmacolite, the $\mathrm{Mg}$ arsenate hörnesite, arsenolite, and As-bearing gypsum $\left(\mathrm{SO}_{4}{ }^{2-}-\mathrm{HAsO}_{4}{ }^{2-}\right.$ substitution). The $\mathrm{Ca}$ arsenates have nearly perfect crystal morphologies and do not preserve any evidence of dissolution; they are highly soluble and as such cannot effectively immobilize As.

\section{Behavior of antimony}

The behavior of antimony during weathering of stibnite is quite different from that of arsenic. Coprecipitation and absorption of $\mathrm{Sb}(\mathrm{V})$ on amorphous $\mathrm{Fe}$ and $\mathrm{Mn}$ oxyhydroxides is rapid and also plays a significant role in controlling the mobility of $\mathrm{Sb}(\mathrm{V})$ in iron-rich weathering environments. However, if the concentration of $\mathrm{Sb}$ is high enough or if the weathering happens in an Fe-poor environment, such as at Lojane, secondary minerals of antimony will crystallize (Filella et al. 2009). Since Fe oxyhydroxides are rare at Lojane and $\mathrm{Mn}$ oxyhydroxides do not exist, $\mathrm{Sb}(\mathrm{III})$ prevails in the mine dumps in the form of $\mathrm{Sb}_{2} \mathrm{O}_{3}$ (valentinite and senarmontite), although strongly weathered stibnite ore has been partly transformed into stibiconite, a mixed $\mathrm{Sb}(\mathrm{III})-\mathrm{Sb}(\mathrm{V})$ oxyhydroxide (Kolitsch et al. 2018). In the Lojane flotation tailings, antimony is mobilized in the form of the RGM phases. Minor amounts of antimony are also found in scorodite (up to 3.8 at.\% of $\mathrm{Sb}$ ) and in the few primary pyrite grains (up to 1.5 at. $\%$ of $\mathrm{Sb}$ ). To date, comprehensive information about the solubility of RGM is missing.

Tripuhyite, a very important Sb-sink in Fe-As-Sb mine wastes, has not been reliably recognized at Lojane in the mining waste (Kolitsch et al. 2018) or in the flotation tailings, which is to be expected due to the Fe-poor environment.

At the Lojane deposit, ore minerals of both As and $\mathrm{Sb}$ formed simultaneously, which is typical for many similar geological environments (realgar/orpimentstibnite mineralizations). Relative to $\mathrm{Sb}$, under nearneutral and oxidizing conditions, As has a higher affinity for adsorption on Fe oxides such as goethite and ferrihydrite (Lalinská-Voleková et al. 2012). The weathering of the $\mathrm{Fe}$-poor realgar concentrate in the 
Lojane tailings, still containing significant amounts of stibnite (up to $13.5 \%$ ), yields a mixture of nanocrystalline RMG antimonates and X-ray amorphous As-dominant RGM-like phases, in which both $\mathrm{Sb}$ and As, and partly $\mathrm{Ni}$, are hosted. These widespread, but volumetrically minor, phases appear as very thin crusts around realgar and stibnite grains, but also as cement between these grains. Slightly Sb-bearing scorodite is also an important product of realgar and stibnite weathering. It occurs mostly as a cement that fills the space among the mineral grains and appears to be the result of rapid precipitation from oversaturated solutions at low temperatures. These conditions of formation might explain the apparent contradiction with the work of Kossoff et al. (2015), who synthesized scorodite in the presence of antimony at $140{ }^{\circ} \mathrm{C}$ and observed that the precipitated scorodite aggregates did not incorporate antimony; instead, tripuhyite $\left(\mathrm{FeSbO}_{4}\right)$ formed as an accompanying phase, the amount of which increased with increasing $\mathrm{Sb}$ in the synthesis. Kossoff et al. (2015) also observed no $\mathrm{Sb}$ in 36 natural samples of scorodite analyzed by EPMA. Since the Lojane scorodite formed at low temperature, seemingly often from a former gel, a metastable incorporation of minor $\mathrm{Sb}\left(\right.$ as $\mathrm{SbO}_{4}{ }^{3-}$ ) in the structure appears possible. Alternatively, our samples might contain nanocrystalline tripuhyite undetectable by our analytical methods. However, scorodite controls As solubility only at $\mathrm{pH}$ less than 3 (DeSisto et al. 2011). Under circumneutral pH conditions, scorodite is metastable and breaks down to iron hydroxides and adsorbed/aqueous arsenate (Nordstrom et al. 2014).

\section{Behavior of nickel and chromium}

The mobilization of nickel during oxidation of Nibearing minerals occurring in the Lojane deposit, such as vaesite, Ni-bearing pyrite (up to 10 at.\% of Ni), and gersdorffite, is reflected in the appearance of minor amounts of secondary annabergite, $\mathrm{Ni}_{3}\left(\mathrm{AsO}_{4}\right)_{2} \cdot 8 \mathrm{H}_{2} \mathrm{O}$, and secondary Ni-bearing RGM (with up to 3.8 at.\% of $\mathrm{Ni}$. Chemical analyses of the tailings samples show the highest $\mathrm{Ni}$ content of $5640 \mathrm{mg} / \mathrm{kg}$ in sample 6a (in which both vaesite and gersdorffite were detected) and the smallest content of $103 \mathrm{mg} / \mathrm{kg}$ of $\mathrm{Ni}$ in sample $6 \mathrm{~d}$. Geochemical studies of soils and sediments in the immediate vicinity of the flotation tailings at the Lojane deposit showed maximum Ni content of 1119 $\mathrm{mg} / \mathrm{kg}$ (Alderton et al. 2014).

Present studies of the flotation tailings material (this work) and the mine dumps (Kolitsch et al. 2018) at Lojane indicate only negligible mobilization of $\mathrm{Cr}$ by weathering processes. Grains of chromite and magnesiochromite show neither rims of any secondary
$\mathrm{Cr}$ minerals formed around these grains, nor $\mathrm{Cr}$ as an impurity element in other secondary phases. These observations are in agreement with literature data on weathered $\mathrm{Cr}$ deposits (Garnier et al. 2008) and are explained by the extreme stability of the chromite and magnesiochromite at low temperatures. Chemical analyses show that the $\mathrm{Cr}$ content in our tailings samples varies between 632 and $796 \mathrm{mg} / \mathrm{kg}$. In soils and sediments in the immediate vicinity of the flotation tailings, a Cr content of up to $595 \mathrm{mg} / \mathrm{kg}$ was measured, with a median value of $285 \mathrm{mg} / \mathrm{kg}$ (Alderton et al. 2014, Tasev et al. 2017).

The influence of microbial activity was not considered in this study, but it is well known that microbes not only are able to oxidize the As(II) in realgar to As(III), and to transform the As(III), which is produced by photochemical oxidation reactions, into As(V) (e.g., Paikaray 2015 and references cited therein), but that they can oxidize $\mathrm{S}$ at the same time (Morin et al. 2003). For example, some sulfate respiratory bacteria and S-oxidizing bacteria can change the chemical speciation and valence state of As in realgar by affecting the form of elemental S. By utilizing $\mathrm{As}$ and $\mathrm{S}$ as their growth substrate, Soxidizing bacteria can change the form and valence of As by combining with chemical reactions during growth (Fisher et al. 2008). On the other hand, in Asand $\mathrm{Sb}$-containing tailings and smelting residues, $\mathrm{Sb}$ was observed to negatively affect several types of bacteria (Courtin-Nomade et al. 2012).

\section{Conclusions}

The unique realgar concentrate in the flotation tailings of the Lojane mine was studied from a mineralogical point of view. The fine-grained concentrate has been oxidizing for at least 40 years. Chemical and mineralogical analyses of the tailings dump show that samples are mostly composed of realgar, quartz, and gypsum, followed by stibnite, pararealgar, sulfur, scorodite, and compositionally variable $\mathrm{Fe}-\mathrm{As}-\mathrm{Sb}-\mathrm{Ca}-$ (Ni)-O(OH) phases belonging to the roméite group. Relic pyrite and vaesite, as well as the weathering products arsenolite, annabergite, "limonite", pickeringite, and alunogen, are present in minor quantities. Secondary phases mostly form the cement among the fine-grained realgar/pararealgar, stibnite, and quartz.

The weathering of primary sulfides in the flotation tailings at Lojane over the past 40 years proceeded under mostly oxidizing, acidic, and temporarily wet conditions. Highly acidic conditions on the surface of the concentrate body imply dissolution of arsenolite and scorodite, thus causing contamination of the environment and high mobility of arsenic. This assumption is supported by high arsenic soil and groundwater 
concentrations determined in close proximity to the concentrate body (Alderton et al. 2014).

The oxidation and decomposition of the realgarrich flotation tailings at Lojane resulted in the formation of various secondary phases whose stabilities affect the release or retention of elements in the near-surface oxidizing and wet environment. The oxidation of primary sulfides releases significant amounts of potentially toxic elements, mostly $\mathrm{Sb}$, $\mathrm{As}, \mathrm{Ni}$, and $\mathrm{Cr}$, which are hosted differently in these oxidation products. The concentration of arsenic is the highest in arsenolite, scorodite, and amorphous to poorly crystalline roméite-type phases. However, minor amounts of arsenic are also present in gypsum, sulfur, and pickeringite, which is explained by the abundance of realgar in the tailings and the consequently $\mathrm{As}^{5+}$-rich weathering solutions percolating through the porous tailings material. This observation shows that migration of As into the environment may also depend on the role of secondary sulfates in the tailings.

The primary oxidation source of antimony is stibnite; during weathering, Sb mostly enters nanocrystalline $\mathrm{Fe}^{3+}$-rich roméite-group phases. The situation at Lojane is similar to that at a historic antimony mine in New Zealand where negligible attenuation of the metalloids $\mathrm{Sb}$ and As (from arsenopyrite) occurred via adsorption outside the adit, as iron oxyhydroxide is rare at the New Zealand mine site (Wilson et al. 2004). At Lojane, antimony is less mobile compared to As; this agrees well with literature data (e.g., Fawcett \& Jamieson 2011, Fawcett et al. 2015).

Considering the only minor presence of pyrite in the Lojane mineralization, the $\mathrm{pH}$-buffering geological environment (e.g., limestone, dolostone, marble, silicified serpentinite), and the carbonate gangue (e.g., dolomite, calcite) that produce neutral to slightly alkaline local waters, it is likely that As and partly $\mathrm{Sb}$ stay in solution and can be transported over greater distances. Furthermore, fine-grained and thus very light tailings material is also subject to continued physical transport via wind, threatening a wider area. The remediation of this environmental hot spot remains unresolved due to local socio-political tensions.

\section{ACKNOWLEDGMENTS}

The financial support of the Austrian Science Fund (FWF) (P 30900-N28) and the Federal Ministry of Science, Research and Economy, Scientific \& Technological Cooperation between Macedonia and Austria 2016-2018 (Grant MK 05/2016) is gratefully acknowledged. We thank Dr. Karolina Schwendtner for assisting during the Rietveld analysis. Reviews by
Prof. Dr. Dave Craw and an anonymous reviewer were helpful in improving the manuscript.

\section{REFERENCES}

Alderton, D., Serafimovski, T., Burns, L., \& Tasev, G. (2014) Distribution and mobility of arsenic and antimony at mine sites in FYR Macedonia. Carpathian Journal of Earth and Environmental Sciences 9, 43-56.

Alexander, B. (2008) Trace element analysis in geological material using low resolution inductively coupled plasma mass spectrometry (ICPMS). Technical Report 18, Jacobs University Bremen, School of Engineering and Science, Bremen.

Alloway, B.J. (2013) Heavy metals in soils: Trace metals and metalloids in soils and their bioavailability, $3^{\text {rd }}$ Edition. Springer Science + Business Media, Dordrecht, Netherlands, 614 pp.

Antonović, A. (1965) Geology, tectonic structure and genesis of the arsenic-antimony ore deposits in the Lojane and Nikuštak district (Skopska Crna Gora Mts). Geological Institute, Skopje, Special Issue 1, 77 pp. (in Macedonian).

Ashley, P.M., Craw, D., Graham, B.P., \& Chappell, D.A. (2003) Environmental mobility of antimony around mesothermal stibnite deposits, New South Wales, Australia and southern New Zealand. Journal of Geochemical Exploration 77, 1-14.

Atencio, D., Andrade, M.B., Christy, A.G., Gieré, R., \& Kartashov, P.M. (2010) The pyrochlore supergroup of minerals: nomenclature. Canadian Mineralogist 48, 673698.

Augé, T., Morin, G., Bailly, L., \& Serafimovsky, T. (2017) Platinum-group minerals and their host chromitites in Macedonian ophiolites. European Journal of Mineralogy 29, 585-596.

BAhFenne, S. \& Frost, R.L. (2010a) Raman spectroscopic study of the antimonate mineral roméite. Spectrochimica Acta Part A: Molecular and Biomolecular Spectroscopy A75, 637-639.

Bahfenne, S. \& Frost, R.L. (2010b) A review of the vibrational spectroscopic studies of arsenite, antimonite, and antimonate minerals. Applied Spectroscopy Reviews 45, 101-129.

Ballirano, P. \& Maras, A. (2006) In-situ X-ray transmission powder diffraction study of the kinetics of the light induced alteration of realgar $\left(\alpha-\mathrm{As}_{4} \mathrm{~S}_{4}\right)$. European Journal Mineralogy 18, 589-599.

Borčinová Radková, A., Jamieson, H., Lalinská-Voleková, B., Majzlan, J., Števko, M., \& Chovan, M. (2017) Mineralogical controls on antimony and arsenic mobility during tetrahedrite-tennantite weathering at historic mine sites Špania Dolina-Piesky and Ľubietová-Svätodušná, Slovakia. American Mineralogist 102, 1091-1100. 
Bosi, F., Christy, A.G., \& Hålenius, U. (2017) Crystalchemical aspects of the roméite group, $A_{2} \mathrm{Sb}_{2} \mathrm{O}_{6} Y$, of the pyrochlore supergroup. Mineralogical Magazine 81, 1287-1302.

Bruker (2017) TOPAS, Version 6. Bruker AXS, Karlsruhe, Germany.

Burton, E.D., Hockmann, K., Karimian, N., \& Johnston, S.G. (2019) Antimony mobility in reducing environments: The effect of microbial iron(III)-reduction and associated secondary mineralization. Geochimica et Cosmochimica Acta 245, 278-289.

Christy, A.G. \& Atencio, D. (2013) Clarification of status of species in the pyrochlore supergroup. Mineralogical Magazine 77, 13-20.

Corkhill, C.L. \& Vaughan, D.J. (2009) Arsenopyrite oxidation - A review. Applied Geochemistry 24, 23422361.

Courtin-Nomade, A., Rakotoarisoa, O., Bril, H., Grybos, M., Forestier, L., Foucher, F., \& Kunz, M. (2012) Weathering of Sb-rich mining and smelting residues: Insight in solid speciation and soil bacteria toxicity. Chemie der Erde - Geochemistry 72, 29-39.

DeSisto, S.L., Jamieson, H.E., \& Parsons, M.B. (2011) Influence of hardpan layers on arsenic mobility in historical gold mine tailings. Applied Geochemistry 26, 2004-2018.

Divluan, S. (1957) Results of the Lojane mine effusive rocks analyses. Bulletin du Muséum d'histoire naturelle de Belgrade: Série A 12, 111-149 (in Serbian).

ĐorĐević, T., Kolitsch, U., \& Nasdala, L. (2016) A singlecrystal X-ray and Raman spectral study of hydrothermally synthesized arsenates and vanadates of descloizite and adelite structure-types. American Mineralogist 101, 1135-1149.

Đorfević, T., Kolitsch, U., Tasev, G., Serafimovski, T., \& Boev, B. (2017) Anomalous As-enrichment in gersdorffite in a realgar-rich environment: Lojane, Macedonia. Mitteilungen der Österreichischen Mineralogischen Gesellschaft 163, 38 (abstract).

ĐorĐević, T., Kolitsch, U., Tasev, G., Serafimovski, T., \& Boev, B. (2018) First insights into the mineralogy of the tailings dump of the Lojane Sb-As(-Cr) deposit, FYR of Macedonia. EGU General Assembly 2018, Vienna, Austria, Geophysical Research Abstracts 20, EGU201814914.

Drahota, P. \& FilipPi, M. (2009) Secondary arsenic minerals in the environment: A review. Environment International 35, 1243-1255.

Dulski, P. (2001) Reference materials for geochemical studies: New analytical data by ICP-MS and critical discussion of reference values. Geostandards Newsletter 25, 87-125.
Fawcett, S.E. \& Jamieson, H.E. (2011) The distinction between ore processing and post-depositional transformation on the speciation of arsenic and antimony in mine waste and sediment. Chemical Geology 283, 109-118.

Fawcett, S.E., Jamieson, H.E., Nordstrom, D.K., \& McCleskey, R.B. (2015) Arsenic and antimony geochemistry of mine wastes, associated waters and sediments at the Giant Mine, Yellowknife, Northwest Territories, Canada. Applied Geochemistry 62, 3-17.

Filella, M., Williams, P.A., \& Belzile, N. (2009) Antimony in the environment: knowns and unknowns. Environmental Chemistry 6, 95-105.

FilipPI, M., DoušovÁ, B., \& Machovič, V. (2007) Mineralogical speciation of arsenic in soils above the Mokrsko-west gold deposit, Czech Republic. Geoderma 139, 154-170.

Filippi, M., Machovič, V., Drahota, P., \& Böhmová, V. (2009) Raman microspectroscopy as a valuable additional method to X-ray diffraction and electron microscope/ microprobe analysis in the study of iron arsenates in environmental samples. Applied Spectroscopy 63, 621626.

Fisher, J.C., Wallschlager, D., Planer-Friedrich, B., \& Hollibaugh, J.T. (2008) A new role for sulfur in arsenic cycling. Environmental Science and Technology 42, 81-85.

FleEt, M.E. \& BARBIER, J. (1989) Structure of aerugite $\left(\mathrm{Ni}_{8.5} \mathrm{As}_{3} \mathrm{O}_{16}\right)$ and interrelated arsenate and germanate structural series. Acta Crystallographica B45, 201-205.

Flynn, H.C., Meharg, A.A., Bowyer, P.K., \& Paton, G.I. (2003) Antimony bioavailability in mine soils. Environmental Pollution 124, 93-100.

Gal, J., Hursthouse, A., \& Cuthbert, S. (2007) Bioavailability of arsenic and antimony in soils from an abandoned mining area, Glendinning (SW Scotland). Journal of Environmental Science and Health A42, 12631274.

Garnier, J., Quantin, C., Guimarães, E., \& Becquer, T. (2008) Can chromite weathering be a source of $\mathrm{Cr}$ in soils?. Mineralogical Magazine 72, 49-53.

Grafenauer, S. (1977) Genesis of chromite in Yugoslavian peridotite. In Time- and Strata-Bound Ore Deposits (D.D. Klemm \& H.-J. Schneider, eds.). Springer, Verlag Berlin - Heidelburg (327-351).

Gripp, K. (1922) Beiträge zur Geologie von Mazedonien. Universität Hamburg, Abhandlungen auf dem Gebiet der Auslandkunde, Band 7 - Reihe C: (Naturwissenschaften) Band 3, $61 \mathrm{pp}$.

Hiessleitner, G. (1931) Geologie mazedonischer Chromeisenlagerstätten. Berg- und Hüttenmännisches Jahrbuch der Montanistischen Hochschule in Leoben 79, 47-57 (in German).

Hiessleitner, G. (1934) Einbruch von Granit und Andesit in Chromerze führenden Serpentin von Lojane, NNW 
Kumanovo in Südserbien. Zeitschrift für Praktische Geologie 42, 81-88 (in German).

Hiessleitner, G. (1951) Serpentin- und Chromerz-Geologie der Balkanhalbinsel und eines Teiles von Kleinasien. Jahrbuch der Geologischen Bundesanstalt Sonderband 1, 1-255 (in German).

Hudson-Edwards, K.A. (2016) Tackling mine wastes. Science 352, 288-290.

JANKović, S.R. (1960) Allgemeine Charakteristika der Antimonerzlagerstätten Jugoslawiens. Neues Jahrbuch für Mineralogie Abhandlungen 94, 506-538 (in German).

JANKović, S.R. (1989) Sb-As-Tl mineral associations in the Mediterranean region. International Geology Review 31, $262-273$.

JAPAn International CoOperation Agency (JICA), Ministry Of Agriculture, Forestry And Water Economy (MAFWe), The Former Yugoslav Republic Of MaceDONIA (2008) The study on capacity development for soil contamination management related to mining in the Former Yugoslav Republic of Macedonia. Final Report, Vol. II, Main Report, March 2008, Mitsubishi Materials Natural Resources Development Corporation, 159 pp.

Keim, M., Staude, S., Marquardt, K., Bachmann, K., Opitz, J., \& MARKL, G. (2018) Weathering of Bi-bearing tennantite. Chemical Geology 499, 1-25.

Klimko, T., Lalinská, B., Majzlan, J., Chovan, M., Kučerová, G., \& PAUl, C. (2011) Chemical composition of weathering products in neutral and acidic mine tailings from stibnite exploitation in Slovakia. Journal of Geosciences 6, 327-340.

Kloprogge, T. \& Wood, B.J. (2017) X-ray photoelectron spectroscopic and Raman microscopic investigation of the variscite group minerals: Variscite, strengite, scorodite and mansfieldite. Spectrochimica Acta Part A: Molecular and Biomolecular Spectroscopy 185, 163-172.

Kolitsch, U., ĐorĐević, T., Tasev, G., Serafimovski, T., Boev, I., \& Boev, B. (2018) Supergene mineralogy of the Lojane Sb-As-Cr deposit, Republic of Macedonia: Tracing the mobilisation of toxic metals. Geologica Macedonica 32, 95-117.

Košek, F., Culka, A., Žáček, V., Laufek, F., ŠKoda, R., \& JEHLIČKA, J. (2018) Native alunogen: A Raman spectroscopic study of a well-described specimen. Journal of Molecular Structure 1157, 191-200.

Kossoff, D., Welch, M.D., \& Hudson-Edwards, K.A. (2015) Scorodite precipitation in the presence of antimony. Chemical Geology 406, 1-9.

Lalinská-Voleková, B., Majzlan, J., Klimko, T., Chovan, M., Kucerova, G., Michňová, J., Hovorič, R., Goettlicher, J., \& Steininger, R. (2012) Mineralogy of weathering products of $\mathrm{Fe}-\mathrm{As}-\mathrm{Sb}$ mine wastes and soils at several Sb deposits in Slovakia. Canadian Mineralogist 50. 1207-1226.
Lengke, M.F. \& Tempel, R.N. (2003) Natural realgar and amorphous AsS oxidation kinetics. Geochimica and Cosmochimica Acta 67, 859-871.

Lengke, M.F. \& Tempel, R.N. (2005) Geochemical modeling of arsenic sulfide oxidation kinetics in a mining environment. Geochimica and Cosmochimica Acta 69 , 341-356.

Lengke, M.F., Sanpawanitchakit, C., \& Tempel, R.N. (2009) The oxidation and dissolution of arsenic-bearing sulfides. Canadian Mineralogist 47, 593-613.

Locke, A.J., Martens, W.N., \& Frost, R.L. (2007) Natural halotrichites - an EDX and Raman spectroscopic study. Journal of Raman Spectroscopy 38, 1429-1435.

Majzlan, J., Lalinská, B., Chovan, M., Jurkovič, L., MilovskÁ, S., \& Göttlicher, J. (2007) The formation, structure, and ageing of As-rich hydrous ferric oxide at the abandoned $\mathrm{Sb}$ deposit Pezinok (Slovakia). Geochimica et Cosmochimica Acta 71, 4206-4220.

Majzlan, J., Lalinská, B., Chovan, M., Bläß, U., Brecht, B., Göttlicher, J., Steininger, R., Hug, K., Ziegler, S., \& Gescher, J. (2011) A mineralogical, geochemical, and microbiological assessment of the antimony- and arsenicrich neutral mine drainage tailings near Pezinok, Slovakia. American Mineralogist 96, 1-13.

Majzlan, J., Drahota, P., \& Filippi, M. (2014) Paragenesis and crystal chemistry of arsenic minerals. Reviews in Mineralogy and Geochemistry 79, 17-184.

Majzlan, J., Kiefer, S., Herrmann, J., Števko, M., Sejkora, J., Chovan, M., Lánczos, T., Lazarov, M., Gerdes, A., Langenhorst, F., Borčinová RadKovÁ, A., Jamieson, H., \& MilovskÝ, R. (2018) Synergies in elemental mobility during weathering of tetrahedrite $\left[(\mathrm{Cu}, \mathrm{Fe}, \mathrm{Zn})_{12} \mathrm{Sb}\right.$, As) ${ }_{4} \mathrm{~S}_{13}$ ]: Field observations, electron microscopy, isotopes of $\mathrm{Cu}, \mathrm{C}, \mathrm{O}$, radiometric dating, and water geochemistry. Chemical Geology 488, 1-20.

Merrow, C.N., Kirkby, S.J., Jensen, J.O., Zeroka, D., \& BANERJEe, A. (2003) Raman spectroscopy of arsenolite: Crystalline cubic $\mathrm{As}_{4} \mathrm{O}_{6}$. Journal of Solid State Chemistry 173, 54-58.

Mohan, D. \& Pittman, C.U., JR. (2007) Arsenic removal from water/wastewater using adsorbents - A critical review. Journal of Hazardous Materials 142, 1-53.

Morin, G., Juillot, F., Casiot, C., Bruneel, O., Personné, J.-C., Elbaz-Poulichet, F., Leblanc, M., Ildefonse, P., \& Calas, G. (2003) Bacterial formation of tooeleite and mixed $\mathrm{As}^{3+} /(\mathrm{V})-\mathrm{Fe}^{3+}$ gels in the Carnoules acid mine drainage, France. A XANES, XRD, and SEM study. Environmental Sciences and Technology 37, 1705-1712.

Naumov, P., Makreski, P., \& Jovanovski, G. (2007) Direct atomic scale observation of linkage isomerization of $\mathrm{As}_{4} \mathrm{~S}_{4}$ clusters during the photoinduced transition of realgar to pararealgar. Inorganic Chemistry 46, 10624 10631. 
Nesbitt, H.W., Muir, I.J., \& Prarr, A.R. (1995) Oxidation of arsenopyrite by air and air-saturated, distilled water, and implications for mechanism of oxidation. Geochimica et Cosmochimica Acta 59, 1773-1786.

Nordstrom, K.D., Majzlan, J., \& Königsberger, E. (2014) Thermodynamic properties for arsenic minerals and aqueous species. Reviews in Mineralogy and Geochemistry 79, 217-255.

PAIKARAY, S. (2015) Arsenic geochemistry of acid mine drainage. Mine Water and the Environment 34, 181-196.

Radusinović, D.R. (1956) The mineral composition and structural features of the sulfide deposit of Lojane. Internal Report, Establ. Nuclear Raw Materials, Beograd, Yugoslavia (in Serbian).

RAdusinović, D.R. (1966) Greigite from the Lojane chromium deposit, Macedonia. American Mineralogist 51, 209-215.

RENOCK, D. \& BECKER, U. (2010) A first principles study of the oxidation energetics and kinetics of realgar. Geochimica et Cosmochimica Acta 74, 4266-4284.

Roper, A.J., Williams, P.A., \& Filella, M. (2012) Secondary antimony minerals: Phases that control the dispersion of antimony in the supergene zone. Chemie der Erde 72, Supplement 4, 9-14.

Savage, K.S., Bird, D.K., \& O’Day, P.A. (2005) Arsenic speciation in synthetic jarosite. Chemical Geology 215 , 473-498.

Schumacher, F. (1954) The ore deposits of Yugoslavia and the development of its mining industry. Economic Geology 49, 451-492.

Schwendtner, K. \& Kolitsch, U. (2007) Octahedral As in $M^{+}$ arsenates - architecture and seven new members. Acta Crystallographica B63, 205-215.

SERAFIMOVSKI, T. (1993) Structural-metallogenic features of the Lece-Chalkidiki zone: Types of mineral deposit and distribution. Faculty of Mining, Štip, Special Issue No. 2, $325 \mathrm{pp}$.

Tasev, G., Serafimovski, T., ĐorĐević, T., \& Boev, B. (2017) Soil and groundwater contamination around the Lojane As-Sb mine, Republic of Macedonia. $17^{\text {th }}$ International Multidisciplinary Scientific GeoConference SGEM 2017,
29 June-5 July, Albena, Bulgaria, Conference Proceedings 17, 809-817.

Trentelman, K. \& Stodulski, L. (1996) Characterization of pararealgar and other light-induced transformation products from realgar by Raman microspectroscopy. Analytical Chemistry 68, 1755-1761.

TuĆAn, F. (1936) Syenite, Granite und Dazite von Lojane in der Skopska Crna Gora. Papers of Yugoslavian academy of sciences and arts 254/79, 29-110 (in German).

United Nations Environment Progamme (UNEP) (2000) Post-Conflict Environmental Assessment - FYR of Macedonia. UNEP, Geneva, Switzerland, 88 pp.

United States Environmental Protection Agency (USEPA) (2009) National primary drinking water regulations. EPA 816-F-09-004, Washington, 7 pp.

Williams, S. \& Marstijepović, S. (2010) Western Balkans environmental program: Case studies on remediation of environmental hot spots in the western Balkans. UNDP Montenegro, $176 \mathrm{pp}$.

Wilson, N.J., Craw, D., \& Hunter, K. (2004) Contributions of discharges from a historic antimony mine to metalloid content of river waters, Marlborough, New Zealand. Journal of Geochemical Exploration 84, 127-139.

Wu, Y., Zhou, X.-Y., Lei, M., Yang, J., Ma, J., Qiao, P.-W., \& CHEN, T.-B. (2017) Migration and transformation of arsenic: Contamination control and remediation in realgar mining areas. Applied Geochemistry 77, 44-51.

Zhu, T.T., Lu, X.C., Liu, H., Li, J., Zhu, X.Y., Lu, J.J., \& WANG, R.C. (2014) Quantitative X-ray photoelectron spectroscopy-based depth profiling of bioleached arsenopyrite surface by Acidithiobacillus ferrooxidans. Geochimica et Cosmochimica Acta 127, 120-139

Zhu, X., Wang, R., Lu, X., Liu, H., Li, J., Ouyang, B., \& Lu, J. (2015) Secondary minerals of weathered orpimentrealgar-bearing tailings in Shimen carbonate-type realgar mine, Changde, Central China. Mineralogy and Petrology 109, $1-15$.

Received December 11, 2018. Revised manuscript accepted March 20, 2019. 